\title{
Chapter Three: The Phantasmagoria of A SECULAR MIDRASH
}

\section{INTRODUCTION}

\begin{abstract}
Mais il ne fallait pas oublier que toutes les folies avaient reçu droit de cité dans mon affaire et s'y étaient donné libre carrière. Il fallait donc pénétrer résolurent dans les arcanes de toute cette fantasmagorie.
\end{abstract}

-Alfred Dreyfus ${ }^{1}$

The prison workbooks or cahiers tell quite another story than that seen in the various collections of letters alone or in the selected and commentated editions discussed already, and these compendia of jottings and drawings expand aspects of what we find in the journals following Dreyfus's return to France. ${ }^{2}$ But why have fewer than half survived? It is not so much because the tropical heat and humidity destroyed them, or because the prison authorities confiscated them, but because Alfred Dreyfus did not wish their contents to be made public. ${ }^{3}$ Yet, as Pierrette Turlais suggests, "If it quickly seems that the correspondence with his wife Lucie and the writing of his journal opened up a source of life, it also

1 "It should not be forgotten that all the madmen were given the keys to the city in my affair and they had a free run. It should therefore be necessary to penetrate resolutely into all the secret passageways of this phantasmagoria." Alfred Dreyfus, Carnets (1899-1907): Après le process de Rennes, ed. Philippe Oriol (Paris: Calmann-Lévy, 1998), 215.

2 Speaking of the Goncourt Brothers Journal, Anatole France defines the genre in this way: "A journal [is] a memorial, a volume of reminiscences [that] escapes all the fashions, all the conventions that are imposed on the works of the mind" ("The Journal of the Goncourts" in On Life \& Letters, first series, trans. A. W. Evans [London: John Lane/The Bodley Head, 1924 (1910)] 74). Though the cahiers do not form themselves into a journal, we could say there are at least two aspects of Dreyfus's personality at work in their composition, one consciously attempting to stave off madness by deliberate intellectual, mathematical, and repetitive exercises, the other unconsciously revealing his pains, his often manic idealism, and his probably little understood Jewish heritage; and these various components of his jotting escape conventions under the outrageous conditions of his treatment on Devil's Island.

3 The fifteen remaining books were donated to the Bibliothèque Nationale in Paris in 1923. The latest discussions on the state of the missing and surviving cahiers can be found in Pierrette Turlais's new limited edition and the fine essays included therein, including her fine "Foreward." 
appears that the unknown part of his writing permitted him to communicate with that same source." What this "source of life" now appears to be is an inner world of intellectual ferment, an expanding and critical ocean of memories-expanding because the more Dreyfus began to write down his thoughts, the more he remembered, and the more he remembered, the more he could compare, weigh, and extrapolate new ideas from these remembered texts. To again cite Turlais, whose critical judgements are sensitive, rich with provocative implications that I will be trying to draw out, and contextualized in a midrashic way:

Whereas the letters and the journal authorized an intimate gushing forth of life and construct, letter by letter, an unfalsifiable memory, the cahiers permit an opening into the world that extends and probably relieves the strict limitations to his self. ${ }^{5}$

The cahiers that survive are those that Alfred Dreyfus wanted to survive, and it is now possible to study them in Turlais's mixed facsimile and transcribed version. Aside from a few, usually scratched-out, beginnings of letters to Lucie or government officials, occasional lists of food and personal items the prisoner wished to request from his guards, and some exercises in learning English, the pages in these workbooks are a mix of doodles, mathematical formulae, reading notes, and translations of the books he was thinking about studying during the nearly five years of incarceration, and finally, perhaps most important of all, Dreyfus's short essays on a wide variety of topics. As Turlais points out, "The inner world of Capt. Dreyfus's exile rests in these notebooks," ${ }^{6}$ and therefore it is important for us to begin to take a measure of how large that inner world really was-or rather, we need to assess its volume, shape, and power of resonance. Most historians of the Dreyfus Affair to date have assumed that it was rather small, restricted not only by the harsh conditions of his imprisonment but by the limited horizons he had as a middle-class provincial from Alsace, an artillery officer, and a Jew.

Therefore, with only some of the cahiers available, everything I have

4 Turlais, "Foreward," 44. All translations from this and other documents in her edition of the cahiers are my own, unless otherwise stated.

5 Turlais, "Foreward," 44.

6 Turlais, "Foreward," 44. 
to say in this book must remain tentative and incomplete. However, even those speculative and fragmentary conclusions that can now be offered will destabilize all previous generalizations about the man, his experience of the milieu in which he found himself by destiny and by choice, the mentalities he shared with those in the various concentric and interweaving circles in which he moved, and the midrashic universe he had inherited, only very small parts of which he knew about or realized he was participating in. These intersecting, overlapping, and sometimes wholly unperceived and imperceptible worlds within worlds are not all composed of his natural languages, mostly French, of course, but also the English he was learning so he could read Shakespeare in the original and also perhaps because he was beginning to think of migrating to North America or the British colonies in the South Pacific, ${ }^{7}$ as well German, Italian, Scandinavian, and Russian languages. These circles within circles were also made of mathematical and chemical symbols and equations, geometrical forms, and line drawings of machines and natural objects. Next to this rational and abstract world of science and technology there lies that far more mysterious realm of his obsessive doodling. In Turlais's words:

And then .... and then an element-what can we call it? - a strange design, abstract, born from an identical structure but ever-changing, comes in to punctuate or mark the stresses of the manuscript hundreds of times. The patterning suggests, over and over again, arabesques, cerebral lobes, demonic rictus, masks or indecipherable heraldic devices. ${ }^{8}$

There are suggestions that these apparently endless drawings represent Dreyfus's attempt to fill time and space and to create a visual correlative of the horrifyingly heavy cloud of silence he lived under night

7 See also Dreyfus's interesting comments on the British colonization of North America and its confrontation with French efforts in the same region, his fascination with Paul Bourget's travel account of a visit to New York City, Newport, and other parts of the United States, and the details of contemporary Australian and New Zealand politics and economy. Was he perhaps thinking of leaving the civilization of France after he was eventually released and going to the Anglo-American culture that seemed to offer more tolerance and freedom?

8 Turlais, "Foreward," Cahiers, 44. See also Comte-Sponville "La leçon d'Alfred Dreyfus" in Turlais, Cahiers, 242. 
and day for all those years. His prison guards, required to examine carefully all his journals and notebooks, as well as letters, were stupefied by these doodles; they could make no real sense of them but suspected that they were kabbalistic signs or secret messages of some Judaic plot or another. As we will keep arguing, the Jew haters of the time-of any time!-may not always be as wrong as we would like to think, not because they are total ignoramuses and blinded by their bigotry and inanity but because they are prepared by these social, moral, faults to notice what "normal" and "liberal" minds do not want to deal with.

So what are these doodles or drawings or cryptic messages? First of all, they are not so much a sign of madness as a deliberate attempt to avoid insanity. In the last several years, unfortunately, we have learned from hostages held by terrorists for long periods of time that worse than physical torment is the mental anguish of being forced to do nothing, to receive no news about the outside world, to experience no sympathy or empathy from one's captors, and to find consciousness shrinking down to almost nothing. It then becomes important, as Dreyfus seems to have discovered, to organize what time and space there is in one's mind on the empty pages of notebooks one is allowed to scribble in and thus to gain a modicum of control over the psychological environment.

Perhaps at the same time, this was an attempt to envisage, embody, and participate in time and space, expanding it beyond the debilitating confines of a bed to which he was shackled for long hours of the night, of a tiny cabin-and one that was replaced by one even smaller in the course of the confinement-poorly ventilated and sparsely furnished, a very small rocky island whose domains he was soon forbidden access to, with even the comforting sight of the sea cut off by the construction of a palisade. Perhaps this psychological (moral) expansion was also aesthetic, metaphysical, intellectual, and spiritual; it was certainly desperate. As Jean-Louis Lévy puts in his preface to Turlais's edition of the cahiers, "For the exiled Dreyfus, automatic drawing is nothing more nor less than strategy for survival." Then he adds, "It is up to us to respect the mystery."

A typical page from the notebook, if we dare suggest such a thing, has the whole surface of textual space filled with hundreds of relentlessly repeated drawings, sometimes fitted around, under, or over the writing 
of words, and all these doodles look alike at first insofar as they emerge from an $\mathrm{X}$ or an $\mathrm{N}$, sometimes from a $\mathrm{Y}$ or a $\mathrm{\gamma}$, but each one distinct in size, shape, and elaboration. In one sense, they correlate with the mathematical formulations; they abstract from the environment, the outer world of hatred and loneliness, the formal patterns of rationality and design. They also correlate to the literary and philosophical texts and intellectual speculations on other pages, especially where Dreyfus engages with his two favourite writers, Montaigne and Shakespeare, and argues with the key nineteenth-century thinkers Michelet, Taine, and Renan. ${ }^{10}$ The drawings affirm that there can be order and reason even in the midst of chaos, and that chaos bows to pattern and order. He argues through his doodles that each individual entity has its own integrity and value, whereas the state, the government, the press, the public, and his prison guards seek to crush him, grind him down into nothingness. I will come back to the problem of these drawings in a later volume, where I will integrate them into Jewish art and aesthetics.

The earlier, now missing, cahiers probably could have revealed how intensely despondent or even suicidal Dreyfus was. That is not quite all guesswork, however, since one atypical journal from the earliest period has survived, inadvertently, in the Colonial Museum at Aix, and has now been discussed and a few pages reproduced in Turlais's volume. ${ }^{11}$ But

10 Turlais, "Foreward," 44. It will be shown in later parts of this book and in subsequent studies of the authors, both creative and historical, that Alfred Dreyfus felt most intellectually drawn to, one of the characteristics he searched for was a commitment to practical applications of scientific and moral ideas. This is also a very Jewish attitude, as we shall show. Although he tried to remain upbeat in his prison notebooks, nevertheless Dreyfus would have agreed with Anatole France that "M. Renan is distinguished by a special feeling of resigned mistrust. He has never had illusions regarding the irremediable uncertainty of human testimony" ("The Errors of History" in On Life and Letters, second series, trans. A. W. Evans (London: John Lane/The Bodley Head, 1923. 1914), 110). Surely one of the great lessons learned from his ordeal, even before he became aware of the full dimensions of the affair that was occurring whilst he was in exile on Devil's Island, is that documents and witnesses, along with experts and judges, cannot be trusted implicitly. For this reason, we may have to reevaluate Dreyfus's attractions to beauty (poetic and natural) over dispassionate discourses of naturalistic fiction or supposedly objective science, when we read Anatole France saying, "For my own part, if I had to choose between beauty and truth, I should not hesitate either: it is beauty that I should keep, certain that it has in it a higher and deeper truth than truth itself" (113). However, as we will give a preliminary report in the final chapter of this book, in Dreyfus's case at least, the argument would need to be contextualized by Jewish concepts of both beauty and truth. One might want all to compare, as France does, this very nineteenthcentury Romantic idealism with what Ernest Renan writes in Histoire du peuple d'Israël; cp. Anatole France's review essay, "The History of the People of Israel" in On Life and Letters, second series, trans. A. W. Evans (London: John Lane/Bodley Head, 1923/1914), 293-299.

11 Maxime Préaud, "Variations à perpetuité" in Turlais, Cahiers, 251-255. This so-called Aix 
although it seems to derive from the very first weeks or months of his exile and there is a gap of about four years between it and the workbooks we do have, it is not easy to determine what the intermediate versions might have looked like or contained, if indeed there were any. Because this somewhat anomalous workbook contains many schoolboy drawings of geometrical figures, some attempts at caricatured faces, and a jumble of plays on the letters of Alfred Dreyfus's name, initials, monogrammatic elaborations, and mathematical equations, Maxime Préaud speculates on a transitional series of developments in the missing cahiers-those that Dreyfus himself suppressed and probably destroyed. But that information cannot be verified, and the very idea of some gradual shifting from the kind of page in Aix Cahier No. 60 to the BNF Cahier 1 dated 3 August, 1898 , seems highly unlikely, for we do not know whether the cahiers that Dreyfus destroyed were regularly or irregularly written over the years before 1898 and 1899_or whether he kept any at all. The evidence from letters and journals suggests otherwise, that is, that the prisoner was too disheartened, depressed, and "detached" to write-that is, that this was some manner of warding off evil spirits from within, as he says, ${ }^{12}$ or that the scribbles, including the drawing of repeated variations on the flowering $\mathrm{X} / \mathrm{N}$ and $\mathrm{Y} / \mathrm{Y}$ were, as the prison reports suggest, "cabalistiques" and "architecturales," meant to engage in the kind of creative intellectual activities the workbooks demonstrate. ${ }^{13}$

What we do know from the extant journals is that Alfred was reading quite a bit, although the kinds of scholarly journals and literature he could receive was limited, both by his own tastes and what Lucie felt she could safely send to him. ${ }^{14}$ There was also a period in which, after new regulations from the Minister of the Colonies in Paris, his wife had

Cahiers is marked as No. 60, and there are two other partial copies made from it listed as No. 63 and No. 64.

12 Anatole France reminds his readers that "it is not from magicians and spirits but from novelists and poets that we must ask the way to the unknown world" ("Hypnotism in Literature," a review of Marfa: Le Palimpseste by Gilbert-Augustin Thièrry in Of Life \& Letters, vol. I, 106). We should add to poets and novelists letter writers, and keepers of cahiers and also remind ourselves of the palimpsest of midrashic writing, whereby rabbinical writers present their arguments in the name and through the words of predecessors and keep occupying the same textual space as the scriptures they claim to explicate and renew.

13 Préaud, "Variations à perpetuité," Cahiers, 253.

14 We have collated various lists and discussed these journals, as well as the known books Dreyfus had in his possession on Devil's Island, in chapter II. There could have been up to three hundred or more actual texts in his personal library, perhaps not at any one time; there would certainly not have been room for them, at best two or three at a time. 
to stop sending him books and journals, and therefore Alfred had to depend on what was available from the prison library in Cayenne. This man, whose Jewish culture elevated books to the highest category of intellectual pleasures, felt the deprivation of reading matter deeply. The receipt of packets from Lucie or from the local library was vital to his sense of self and sanity. ${ }^{15}$ Given the hundreds and hundreds of titles and authors he refers to, it also is more than likely that the bulk of the books, authors, and themes he writes about derive from his memory of what he had read and studied as a boy, from the literature he and Lucie discussed in their fireside chats in the evenings, and from phrases, images, and ideas sparked off by references in the various magazines he could receive from time to time. Certainly, his beloved Montaigne's Essais was a rich anthology of quotations and paraphrases.

The pages of these fourteen remaining cahiers contain more than just the reading notes and exercises in translation that Turlais and others have noted. There are also a few prose poems, lists of aphorisms and apothegms of his own composition, technical discussions on bicycles, photography, economics and meteorology, and speculative mini-essays on politics, aesthetics, rhetoric, historiography, and education. ${ }^{16}$ I have

15 Bloch-Dano: "Les livres font partie de son univers mental, et reflètent une culture, vivante qui n'a rien à voir avec une occupation mondaine. Jeanne [Proust] est bien représentative de ce milieu israélite pour lequel la vie intellectuelle est primordiale, et jugé supérieure à toute autre activité" (Books were a part of her mental universe, and reflected a living culture which had nothing to do with a worldly occupation. Jeanne Proust is a good representative of this Jewish milieu for whom intellectual life is primordial and judged to be superior to all other activities), Madame Proust, 156.

16 Perhaps the shape and contents of Alfred Dreyfus's workbooks recalls the Talmudic commentaries created over generations by the rabbis. Important to this conception was the institution of the kalla, which according to José Faur, was "a month-long convention, during which students and sages from all over the Jewish world gathered to study a Talmudic tractate . . . There were two Kalla meetings per year, one in the month of Afar (winter) and another in month of Elul (summer). In addition...the Kalla was attended by outside students and sages, as well as by the magistrates and highest judicial and political officials of the nation." Then Faur draws the important analogy, which we extend to Dreyfus's cahiers, comparing larger to smaller things: "Just as the Synagogue is a virtual experience of the Temple, and the liturgy of the sacramental services, so the Talmud is a virtual Kalla experience. Through the Babylonian Talmud, students and sages from the fragmented Israel have unfettered access to the Kalla world and hear the voices of Jews from Tiberias and Caesarea, from Lydia and from Sippore, from Nehar De'a, from Fum be-Dita [sic] and from Sura, and from countless other seats of learning and as one, pupil and teacher, learned and common, disciple and sage, brilliant and mediocre, share in their discussions, reflect on their ideas, and renew their bonds with an integral Jewish society. This is why the Talmud is much more than a book or a landscape of things lost; it is a virtual Kalla, a holistic experience . . . . Hence the folklore, exegesis, psychological insights, esoteric and metaphysical meditations, stories and tales, crisscrossing the legal principles and doctrines taught by the sages" (The Horizontal Society, Section IV, 46). 
compiled three indices in the Appendix in the next book in this series to show (a) the books and authors Dreyfus refers to, (b) the topics he writes about, and (c) the mathematical and scientific notions he names in relation to the formulae and equations he plays with in the cahiers. ${ }^{17}$ Given that we only have the notebooks of 1898 and 1899, the range of reading is nothing but amazing, particularly as these were the last frustrating and painful years of his horrible nightmare.

What were the books Dreyfus was reading and thinking about? Montaigne and Shakespeare, to be sure, as Turlais points out ${ }^{18}$ - and as everyone who has glanced at the manuscripts has recognized, he taught himself English so as to read the great Renaissance playwright in the original. Yet there is much, much more. He also read and commented on nineteenth-century authors such as Hippolyte Taine and Ernest Renan, Jules Michelet, and Paul Bourget. He calls the first three amongst the most important of his century and points to the fourth as his teacher from lycée, with whom he had maintained contact. Taine, Renan, and Michelet are, for the compiler of these cahiers, more than just historians; they are great stylists, teachers, and poets, while Paul Bourget is a popular novelist but also a psychologist.

Although Marcel Proust did not like his style of psychological fiction-he thought Bourget explained too much, according to Anatole France $^{19}$ - Bourget belongs to the school of Hippolyte Taine, and this makes Dreyfus doubly within that tradition as well. Literature, in the sense of belles-lettres rather than a more strict construction of creative writing or even fiction, should be morally and psychologically true; instead of the self-indulgence and introspective tendencies that became

17 I have also added a brief comment on the nature of the mathematical, chemical, and physics formulae in the workbooks prepared by Ken MCNeil, a former colleague in the Department of Humanities, University of Waikato.

18 Turlais, "Foreward," Cahiers, 44.

19 Dreyfus is not alone in such tastes and evaluations, as we can see in a remark made by Anatole France, "Science and Morals: M. Paul Bourget" trans. Bernard Mill, On Life and Letters, Third Series (London: John Lane, The Bodley Head, 1924): "By his method and general bent of mind he [Bourget] belongs to the school of $\mathrm{M}$. Taine, for whom he professes a legitimate admiration, and he is not without intellectual affinity with M. Sully Prudhomme, his senior as a poet" (53). (Prud'homme was another poet Dreyfus admires in the cahiers.) In this essay, France discusses Bourget's latest novel Le Disciple. Most significant is the fact that although Dreyfus gained the support of and often became friendly with writers in the Naturalist School, such as Emile Zola, his own predilections belonged to a more conservative group of writers concerned, as France entitles this essay, with Science and Morals. See also France's discussion of Un Coeur de Femme in "Paul Bourget," On Life and Letters, 4th series (London: John Lane/Bodley head, 1924, 1925), 21-28. 


\section{prevalent in the 1890s and beyond, this form of discourse serves society and the individual reader through its ability to express its liberal ethic through clarity of style. It is a literature of wit and scepticism, intellec- tual and fluent. ${ }^{20}$}

20 Cp. The witty ironies in Anatole France, The Amythst Ring, trans. B Drillien (London: The Library Press, 1899), where one of the characters, the Duc de Brécé, explains to a gathering of important friends in his rural chateau: "I am convinced ... that the fuss made over this affair is, and can only be, some abominable plot instigated by the enemies of France” (17). And when the Abbé Guitrel says who these enemies might be- "free-thinkers, and freemasons . . Protestants," Brécé adds pointedly. "And Jews . . . Jews and Germans. What unheard of audacity to question the decision of a court martial! For, when all is said and done, it is quite impossible for seven French officers to have made a mistake" (18). Still further, the Duke continues, ominously foreshadowing events forty years later under the Nazi regime: "the Jews will bring misfortune upon France. Why don't we get rid of them? Nothing could be easier" (20). The fear he and his friends express was all too common during the affair, even among those clever and honest enough to see through the smoke screen to Dreyfus's innocence: "For when all's said and done, the Army is all that is left us . . . That is why I insist that to meddle with it is nothing short of sacrilege" (49). Many of these good Frenchmen in Anatole France's novel are not slobbering racists but fervent conservative patriots. Thus, speaking of the Baronne de Bomont, a converted Jew, the curate explains, "What I mean is that she has been converted and baptized, and is therefore a Christian. She is a good Christian, I might add, and gives largely to our charities ..." However, Brécé interrupts his friend and reveals himself as an anti-Semite of a more racist and rabid variety: "To me a converted Jew remains a Jew; I cannot make any distinction between them" (62) The abbé tries to wriggle out of this problem by arguing "that the curse pronounced against the Jews was inspired by their crime, and not their race and that therefore . . ." but the duke diverts the conversation to something else. Only later does the novel return to the subject of Jews and a discussion on "anti-Jewish frenzies" (82). In another anecdote, concerning a duel fought between Raoul and Isidore Mayer, the issue was the fact that the true Frenchman refused to allow the Jew to touch a book containing a list of military officers because "It is sacred to the French Army!" Mayer asks why Raoul is so upset, and the answer is: "Because you are of the same religion as the traitor!" (89). In other words, while exposing the graft and pettifogging nature of small town elites, France weaves in and out of their stupid conversation allusions to the Dreyfus Affair and attitudes that run the gamut of rabid to mild anti-Semitism. Some of the characters, like M. Letterier and M. Bergeret, express a more liberal, tolerant view of both the case against and the person of Dreyfus, but they are basically ineffective and comical persons. Outside in the streets, the mobs march, shouting, "Mort à Zola! Mort à Leterrier! Mort à Bergeret! Mort aux juifs!" (148). In another place, another cry is added: “Conspuez Leterrier!" or "Conspuez Bergeret!" (190), that is, "Spit on them!" For most people, then, the Dreyfusards are a "syndicate of treachery" (168) and anyone who expresses sympathy for or belief in Dreyfus's innocence is himself "a Jew, a Prussian, an 'Intellectual' . . ." and their opinion "was bought" (187). Greater scorn is heaped on such stupidity by Bergeret, a favorite and repeating character in France's stories and novels, when he confronts M. de Terremonde and tries to convince him that Jews are assimilable. But the self-proclaimed anti-Semite will not be moved. Prof. Bergeret then warns him to be careful of Jehovah: "If I were in your place, I would beware of Him. He was a Jew at heart, and who knows whether He has not always remained a Jew? Who knows whether at this moment He is not avenging His people?" (258) As Terremonde rides away from the professor of Latin, the spokesman for the author shouted "Beware! . . Do not keep their God" (259). The novel closes at about the time of Colonel Henry's suicide, an event that forced all but the most die-hard anti-Dreyfusards to give up their cause, and they, rather than own up to their error, simply slink away into the darkness (278-279). 
At the same time, always in solitary confinement, always at the confluence of rage, despair, nostalgia, and madness ${ }^{21}$ —indeed, at times, he veers away from his stated topic, with a cri du coeur or a long-repressed memory of infancy or schooldays-Dreyfus was working through and learning from the technical journals he was sent, exercising his professional skills, attempting to keep up with advances in science, and maintaining his grip on secularism and sanity. Recall that he was by profession and training, after all, a military engineer. While he writes little essays on the technical problem of inclines on the curves of railway lines or the way to improve the recoil in rifles and cannons, his mathematical formulae seem to be most concerned with abstract geometrical forms. At times, too, he writes out chemical equations, sometimes connected to an understanding of the human body as an organism and sometimes to changes in the weather. In a way, he is reassuring himself that the natural world - kept apart by all sorts of physical and moral barrierswas rational, orderly, and sane, no matter how absurd and hostile the political and juridical realms might have become for him.

In addition to his literary, historical, and scientific essays and notesand we also need to point to the several descriptive passages that seem effectively to be nothing less than prose poems - there are the many pages of various drawings. ${ }^{22}$ These drawings perhaps are the most unusual and fascinating feature of the prison notebooks. Yet my argument is that they should not be treated as separate from all the other modes of composition and speculation in the cahiers.

The modern biographers of Dreyfus, if they touch on his intellectual formation at all-and some even saw the notebooks in the Bibliothèque Nationale before they were made public at the end of 2009_at best seem to ask why he spent so much time with classical texts such as Homer and Cicero or Renaissance authors such as Montaigne and Shakespeare, or Racine and Corneille. Their reading is superficial and inadequate. Look at the appendix of the next book and you will see a much longer list and a much wider range of authors, with Dreyfus citing

21 One can justly compare Dreyfus's prison notebooks therefore with not only Job's complaints from the dung heap or Boethius's search for a consolation of philosophy from his cell in Ravenna but also various nineteenth-century exemplars we will discuss anon, as well as comparing Dreyfus's imposed isolation with the self-chosen experiences of Gauguin in his tropical dreamland and Proust in his cork-lined bedroom.

22 It is estimated Dreyfus drew more than 25,000 of these "petits desseins." 
many eighteenth- and nineteenth-century writers in French, English, Latin, and sometimes in Italian. Most of the time, as we examine the list, it is clear that the closer he comes down to discussing his own time and place (that is, France in the fin de siècle), he not only talks about philosophers, historians, psychologists, and scientists but also discusses painters, musicians, poets, dramatists, and novelists. Sometimes he is quite up to date, as when he refers to Eugene Brieux's play Les Bienfaiteurs published in 1896. Although he does not mention all or even a few of the avant-garde cultural figures, he knows enough to have opinions, ${ }^{23}$ and his tastes and predilections are for more traditional, more bourgeois, and, one might say, more practical authors and artists, practical in the sense that they were concerned with the world more than with themselves. Hence his admiration of Michelet, Renan, Taine, and Bourget.

However, it is not enough to ask how many authors and texts he read or recollected during the years on Devil's Island, nor just to set them out in columns by period, language, and topic. Such exercises certainly enhance our view of Dreyfus's wide reading, but they do not express all his interests in European culture. After all, as we have observed, he seems not to be concerned with any of the avant-garde movements in the arts or the most radical advances in mathematics, psychiatry, or philosophy, and in fact, when he approaches them, he backs off with boutades against the art for art's sake programmes and rejects the inherent absolutism and racism in many of the so-called philosophical ideas of the fin de siècle. It is therefore important to go beyond those lists and explicit statements of taste and opinion. Who appears most often, both explicitly by name and by implication in the preferences and likes Dreyfus expresses? When he does comment on books and authors, which passages does he focus on or choose to translate? And does he develop a kind of theory of literary or historiographical criticism that blurs the distinction between genres, because he believes that a moralized aesthetic should obtain in all cases? At times that seems to be the conclu-

23 On the importance and uniqueness of "opinions" in the nineteenth century, see Tarde, L'opinion et la foule, esp. 73ff. Rather than well-crafted traditional statements of belief and philosophical or political ideology that could be taught in schools, as well as preached in churches and other institutions of public faith, the new bourgeois individual of the modern age was forming "opinions" of his or her own based on private experience, and crowds were coerced or seduced into "public opinion" by the emergent mass media, such as newspapers, magazines, and best-selling books. 
sion one must reach, and yet Dreyfus is too often questioning himself as well as his authorities to arrive at any one fixed point. Perhaps, while he was in prison under his onerous conditions of exile and solitary confinement, he was allowed-or rather, allowed himself, dare we say?-the luxury of thinking through matters that he had never had the time or opportunity to deal with before.

In his commentaries on the more recent authors of the eighteenth and nineteenth centuries, while he often considers their moral and political positions, he does keep turning the argument towards-or has sudden slides into-consideration of aesthetics and the artistic temperament or personality. And yet, while he pays close attention to matters of style and form, he rejects the notion of art for art's sake. What also comes through in these choices and ways of questioning and challenging the books and persons he deals with is his rabbinical attitude and method, again something as evident in the product of his musings as absent in any direct way of allusion or citation.

\section{PART 1: MIDRASHING THE CAHIERS}

He [Hillel] used to say: If I am not for myself, who will be for me? And being for my own self, what am I? And if not now, when?

-Pirqe Avot, 1:14

My memory, even my involuntary memory, had lost all recollection of the love of Albertine, But it seems that there is also an involuntary memory of the limbs, a pale and fruitless imitation of the other kind, which lives on longer, rather as none non-intelligent animals or vegetables live on longer than man. -Marcel Proust ${ }^{24}$

The very first little essay in the prison notebooks appears on folio 2. Let me cite it in full to give some idea of what it is all about and how Dreyfus works:

24 Marcel Proust, Finding Time Again (1927), vol. 6 of A la recherché du temps perdu, trans. Ian Patterson (London: Penguin Classics, 2004), 5. 
"The Virtues are lost in self-interest as rivers in the sea"-from La Rochefoucauld

The idea is reiterated by D'Annuzio in The Triumph of Death I believe, and it is admirably developed in a poetic form. It struck me when I read it, but I could only recall the germ of the thought, resting on the maxim of La Rochefoucauld, It is so true that ideas that guide human nature remain eternal; one can only rearrange them or modify their form, the better to appropriate the expression. ${ }^{25}$

Self-interest is, of course, the common term for egotism and greed in the world before our own, when it has come, if anything, to mean the goal and essence of one's life. Dreyfus belongs to a traditional world of moral values, and he recognizes a commonplace in the contemporary Italian's poem, assigning its clearest expression to the French aphorist of the seventeenth century. He draws the analogy from memory, not an available encyclopaedia of citations. He then states the rhetorical principle that the truest ideas are those that form part of the universal tradition, rhetoric here meaning not only a school discipline or a technique of formal argumentation, but a body of knowledge: what is known is knowable and memorable precisely because it has already been shaped into memorable sentences and mental images. This grounds Dreyfus firmly in his own civilization and, at the same time, as we will be showing, permits him to express his own Jewishness in modes of argument and thought that overlap with the secular and Christian heritage of French education. ${ }^{26}$ If the virtues are lost in self-interest and run into the vast sea of confused and meaningless experience, it is because this ideal of an ethical life must keep orienting itself to both the social world of human relationships (including politics) and a more transcendent world of religious and philosophical ideas.

On the same folio page of the first extant cahier, Dreyfus places a

26 Faur: "Since times of yore, Jews have been absorbing ideas and values from other civilizationsthat is a fact. What is significant is what they chose to absorb and what they chose to reject" (The Horizontal Society, Section V, 56). Hence, we need to examine what Dreyfus chose to read and comment about, what he puts aside as relevant and what he chooses to question and challenge. 
short crucial essay on Pierre Loti. To understand it as typical of the prison notebooks, the whole text needs to be cited and analysed closely:

The Dust, Galilee, Jerusalem by Pierre Loti

Very inferior to his earlier works. No psychology. A great intensity of picturesque sentiment, perception and melancholy things, fugitive and vague images, an incurable delusion. A very correct and vibrant notation of vague and changeable states of nature, a piercing acuteness of perceptions and sensations, but without arriving at any moral conclusion. All that one can say about these books is that Loti has fixed the most mobile and strange aspects of nature with a surprising justness, and that is all. Raimundo by Loti. Quite superior to and distant from these travel books describing the stages towards Jerusalem. He disengages his personality to write a simple and natural human work. Admirable descriptions of Basque life. ${ }^{27}$

In the telegraphic prose of this critical essay, Dreyfus measures and compares books by the very popular Pierre Loti. They may have been among the "easy little books" he had first asked Lucie to send him when he knew he was being transported to Devil's Island. Of the first three travel books about a journey to the Holy Land, Dreyfus sees how superficial and facile they are, yet he is also aware of the reason for their popularity: they are slickly written and pander to popular tastes for the exotic, the picturesque, and the sentimental. Without psychology, that is, with no consideration of the way the mind receives, processes, and evaluates the scenes Loti so aptly describes, there is no lasting value in the books. The best one can say about them is that they reproduce static pictures, postcard views of what was then still called Palestine. However, in Raimundo, Loti succeeds in delving into the character of the lead character in order to arrive at the essence of the Basque people and culture. Although he does not mention it, the first three books come close to evoking the Land of Israel, the older Jewish settlements, and 
what was beginning in the last two decades of the nineteenth century, the new Yeshuv, the return of Jews to their ancestral homeland and the beginnings of political Zionism. It may be said, on the basis of what we uncovered in our long analyses of the letters between Alfred and Lucie, that this period of martyrdom on Devil's Island was the beginning, albeit aborted or at least deferred to unconscious workings-out, of his own moral journey to Jerusalem.

Following this literary excursion, Dreyfus writes down, seemingly at random, some verses in Latin from Virgil:

Ah! miseram Eurydicen! anime fugiente vocabat:

Eurdicen toto referebant flumine ripae. ${ }^{28}$

... with fleeting breath, called Eurydice-ah, hapless

Eurydice!

"Eurydice" the banks re-echoed, all down the stream. ${ }^{29}$

These two lines are taken, whether from some passage in Montaigne or from his own schoolboy memories, from Virgil's Georgics, Book IV, lines 526 and 527. They describe how Orpheus, ever lamenting the loss of his wife, whom he was forced to leave in the underworld because she had broken the regulations on looking back once her husband had rescued her from the clutches of Dis, Death, was torn apart by the frenzied maenads, and his head was thrown into the river Hebrus. As it is swept down the rushing current, the severed head sings the name of his wife over and over again, with the banks echoing his lament. Aside from the sheer beauty of these poetic lines by Virgil, one must ask why Dreyfus cites these lines and why here? ${ }^{30}$ In the first place, the prisoner feels cut off and helplessly separated from his beloved wife Lucie. Invisible and mysterious forces that seem to have broken apart his domestic life and his professional career are sweeping him along. Second, it is not only a madness that rips up apart his life, but a madness within himself, the

28 Cahiers, 52.

29 Trans. H. Rushton Fairclough, Virgil, Aeneid and the Minor Poems, vol. I, Loeb Classics (London: William Heinemann and Cambridge, MA: Harvard University Press, 1966 [rev. ed. 1934, orig. 1918]), 233.

30 Hillel the Elder: "Moreover he once saw a skull floating on the face of the waters. He said to it: For drowning others thou was drowned; and they that drowned thee shall be drowned" (Pirqe Avot $2: 7)$. 
frustrations and rage that he can barely contain arising from his longstanding hypersensitive disposition and enervation exacerbated by the tortures of the prison authorities.

Still on this second folio page, Dreyfus cites in English Shakespeare's Othello, III.iii, the speech by Iago:

Who steals my purse steals trash; 'tis something, nothing;

'Twas mine, 'tis his, and has been slave to thousands:

But he that filches from me my good name

Robs me of that which not enriches him

And makes me poor indeed.

Although a modern literary scholar would see the words of this archvillain as darkly ironic, given Iago's evil and Machiavellian intentions against the tragic Moor, and as much a tissue of commonplaces as Polonius's rodomontades in Hamlet, for Dreyfus it is these very time-worn expressions that encapsulate his own feelings, otherwise almost inarticulate in his nervous condition. Throughout the letters, we have seen Lucie and Alfred repeating their frenetic need to clear the honour of the family name, and this compulsive impulse drives virtually everything Alfred reads, thinks, and writes about. ${ }^{31}$

Thus, it is not out of nothing that Virgil's lines or this speech from Shakespeare appear on the pages of the workbooks. They are deeply constitutive concepts of his whole project in writing out and so creating an intellectual refuge from the terrible machine grinding him down every day and every night. Dreyfus does not seek refuge in great books and ideas only to escape from the tortures he is undergoing: he works hard to create this alternate space and to draw out of his deepest memories aspects of his own personality he was not normally engaged in developing, and he wrestles with the angel of his own intellect to make his self viable in the harsh, agonizing environment he cannot deny. Like with Jacob, though, it takes more than just enduring a whole long night to emerge victorious in the morning with a new

31 "For Judaism, the world is like a great family, where the father lives in immediate contact with his children, who are the different peoples of the earth .... In heaven a single God, father of all men alike; on earth a family of peoples, among whom Israel is the 'first born, charged with teaching and administering the true religion of mankind, of which he is priest." Elijah Benamozegh, Israel and Humanity, trans. and ed. Maxwell Luri (New York and Mahwah: Paulist Press, 1994), 53-54. 
name; it also means being wounded and realizing that the victory is far from complete. Jacob gains a new name, Israel, and a new determination in his life, while for Dreyfus the return to his ancestral identity is more complex and subtle.

In the very next little essay, he attempts, on the verso of folio 6 , to confront one of his favourite authors, Ernest Renan, and begins to wrestle with a theme that bothers him many times throughout the surviving cahiers:

From Renan: "The study of literary history will replace in great part the direct reading of works of the human mind." I am grieved to find myself in absolute disagreement with Renan. The study of literary history can only complete direct reading of works of the human mind. ${ }^{32}$

Having decided in some sort of conscious way to fill his cahiers with intellectual matters of various kinds, as we have noted before, Dreyfus now has to rationalize what he is doing, that is, justify to himself the project according to his circumstances-he does not have a large library to draw on or colleagues to consult; he has limited space, time, and energy, and even further, limited emotional focus in which to contemplate the ideas he wishes to write out. So here for the first time, we can see him starting to engage with his intellectual masters; he confesses that he disagrees with Renan-absolutely. As though prescient with foresight into the postmodernist obsession with theory over substance and the death of an author in a mode of criticism that "privileges" the critic over the creative artist, Renan laments that direct experience of works of the human mind will have to give way to secondary texts. ${ }^{33}$ In a sense, this is the old Platonic problem of mimesis, of art as an imitation of reality, and so less perfect, if not a mere hollow and shallow shadow of the original, and then critical essays or histories of the imitations as even more distorted and inane compositions, divorcing each new generation

33 Compare that to another of Dreyfus's favourite authors, Hippolyte Taine: "The modern method which I strive to pursue, and which is beginning to be introduced in all the moral sciences, consists in considering human productions, and particularly works of art, as facts and productions of which it is essential to mark the characteristics and seek the causes, and nothing more" (The Philosophy of Art, trans. John Durand. [New York: Holt \& Williams, 1873] 37). Dreyfus does not limit his method to such a positivistic science and seeks something more than physical facts. 
from its ability to enter into a living dialogue with the products of human cogitation and speculation. ${ }^{34}$

Such questions, though, seem appropriate within a culture formed on Hellenistic ideas of art as imitation and texts as arguments whose basis is in historical facts and testimonials shaped by tendentious drives, while a Jewish point of view argues in a different way altogether, stating that mankind, formed in the image of God, seeks to enhance and develop that image so as to participate more fully in the divine creativity and that textuality moves in and out of direct contact with the earliest intellectual voices, enlivening them at the same time as making them enhance the individuality of the latest and future voices.

Consequently, at a seemingly mundane level, Dreyfus begins to advance his thought by proposing contra Renan that "the study of literary history can only complete direct reading of works of the human mind," for this kind of secondary approach to direct experience of another mind than one's own,

[which] coordinates the elements, minimizes the obscurities, makes comprehensible the transformations, the influence exercised by the surrounding milieu and current ideas.

These criteria for conducting and evaluating the critical programme would undermine the wall set up by Renan between direct access to an author's creative energy and excitement and the student, who he fears will only encounter the lesser mind of the historian or reviewer. Dreyfus sets out the parameters of a critical theory that uses the developing

34 According to Ouaknin, there are three steps in mahloquet, the rabbinic manner of questioning and challenging a text in pairs: study and thought are the necessary preparations for entering into such a dialogue of learning; it is not a simple exchange of ideas through question and answer, as in a Socratic dialogue, with its maieutic of recalling what was what once known and has been forgotten but a constant process of sheylot-ou-t'shouvot, questions and challenging responses, and finally the dialogue does not take place on the same level of thought-it creates a new dimension of thought (Tsimtsoum, 111). This new level of understanding where truth is constructed is a shared interiority, shared by the interlocutors themselves and with God who is always a participant as well (112). This is what Lucie and Alfred believe they are constructing in their letters, a language-world at a different level of experience than they have ever known and that is beyond the understanding of the censors reading their epistles. He also believes he is creating something of the same sort in the various workbooks he fills out, in dialogue with himself, with the authors he reads and recollects, and with the man he hopes to become through the whole exercise. 
secondary texts to create an approach that directs the student through a well-shaped course of study towards contact with ancestral minds, shadow voices that would otherwise recede into obscurity by the passage of time. History conceived as both the accumulation of differences and the loss of points of direct contact can also be reconstructed in this way to become a roadmap that takes advantage of hindsight, each advance into the future at the same time being a clarification of what happened in the past and how its meaningfulness has become more evident with the realization of its potentialities. The reason Dreyfus prefers Renan, Michelet, and Taine, for instance, rather than say Sainte-Beuve or Thiers, ${ }^{35}$ is because these moral teachers take into account the transformations, the influence of surrounding milieu, and the current of ideas. To find out how they do this takes up much of his mental energy.

But first he needs to affirm for himself that "never will anything be able to replace direct reading of great works of the human mind." By this he means more than reading old authors in their original languages, or more recent philosophers and historians in their pristine texts, rather than a schoolbook résumé and dumbed-down popular paraphrase; these original readings require introductory essays, generous annotations and glossaries, and translations into contemporary languages. For what purpose?
A moral or intellectual emotion will never be produced except by direct reading of great works; the ideas they stimulate, that they arouse in passing in the conscious- ness and then the unconscious provokes in the mind a form of elevated character. ${ }^{36}$

35 Although he is critical of these authors, Dreyfus came to them because, as Anatole France put it in terms of one: “The 'Histoire de la Révolution' and the 'Histoire du Consulat et de l'Empire,' by M. Thiers, were, for more than thirty years, the books most read in France, if we except 'Les Trois Mousquetaires,' which it will be admitted, does not belong to the same class" ("M. Thiers as Historian," on the occasion of the inauguration of the monument to him at Père-Lachaise in On Life \& Letters, I, 209). Dreyfus would therefore have read Thiers and Sainte-Beuve in school and he can now, with a more mature mind and a sensibility honed by the nightmare, reflect more wisely on the tasks of a historiographer.

36 Note that my translations attempt to follow Dreyfus's own often halting syntax, hesitations, and repetitions. Instead of crossing out and rewriting to polish his style, he starts again in several places to write new versions of these essays that are so important to him. Sometimes, though, he starts and then crosses out and moves on to something else, and even, rarely, he starts his essay, then is diverted to something else-and when that something else is highly personal, such as a memory of his childhood or a cri du coeur in reaction to current torture, frustration, and 
The purpose of reading, he argues here, is to come into direct contact with another human mind through its intellectual and artistic productions, and that contact is stimulating, inspiring, and creative in itself. The purpose is to create a character of a high moral kind. These developments should happen both to the conscious and the unconscious mind-but what can Dreyfus mean by "unconscious" in 1898 when he is writing these notebooks? This is the time when Sigmund Freud was only beginning to develop his theories of the mind as overwhelmingly composed of drives, passions, impulses, memories, and anxieties mostly below or outside the range of volitional control or awareness. Poets and philosophers throughout the nineteenth century had been probing the limits of the conscious mind, and some, following Rousseau, had already been asserting the primacy of secret inner realms over distorting socially-constructed paradigms of personality, thus seeking out primitive, folk, and exotic models and experiences. Others, like Nietzsche, sang the praises of violent emotions and actions over peaceful and contemplative lives.

In rabbinical writings, however, the unconscious was what was either forgotten and could be learned through study under careful guidance or what was not yet articulated and realized, so that an interpretation of a text would be measured by how far it enhanced, clarified, and made relevant ancient pronouncements and narrative exemplars, and ethical life always sought to adjust and thus advance the applications of the law in such ways as were most just and compassionate..$^{37}$ For Dreyfus, too, reading to be inspired and challenged by great works of the human mind was a moral act with the purpose of making himself and other students wiser and better able to cope with adversity. He would certainly have agreed with most of what is in Pirqe Avot, the Ethics of the Fathers, the highly aggadic book of the Mishna traditionally read aloud in the synagogue during Sabbath services between the end of Passover and the start of the New Year, through the northern hemisphere summer. For example, Simeon, the son of Rabbi Gamliel, is quoted as saying,

loneliness, we shall take special note of those moments.

37 In an ambiguous and perhaps teasing tone, see Romain Rolland: "Kindness is not a rare quality with the Jews: of all the virtues it is the most readily admitted among them, even when they do not practice it" (Jean Christophe, Vol. II, 379). 
All my days I have grown up among the wise, and I have found naught of better service than silence; not learning but doing is the chief thing; and he who speaks profusely causes $\sin .$. By three things is the world preserved: by truth, by judgment, and by peace ... ${ }^{38}$

Whether Alfred Dreyfus ever read these words himself or heard them recited in synagogue during the summer months, ${ }^{39}$ they nevertheless resonate within his own objections to Renan, ${ }^{40}$ a teacher he respects but whose pronouncements he cannot accept without question or challenge:

The study of literary history is the domain of criticism, the realm of purely subjective science. The reading of great works is the domain of the objective, preserved in the light of awakening wise and intellectual ideas. One must therefore see in Renan's phrase a mere whim [une boutade] or, more likely, his mind was tending towards the same criticism, philology...

Look at what he says here: literary criticism is the zone of the subjective whereas direct reading of those texts is objective. This is what we now call "counterintuitive." It is a witty paradox, an overturning of the expected, commonsense judgement. He seems to dismiss Renan's remark as a joke or a whim and calls such criticism philology. But what Dreyfus actually meant to say here we cannot tell, because the final four lines are rubbed out.

What he wishes to say, though, is suggested by a second version of this same essay, which he wrote on the verso of folio $11 .{ }^{41}$ Skipping over

38 Pirqe Avot, 1: 17-18.

39 Idelsohn: "One of Judaism's chief features is its staunch adherence to and fearless proclamation of the truth, however painful to personal vanity that truth may be" (Jewish Music, 78); or put another way, no matter how painful and dangerous it may be to the individual or community forced to live in a hostile society.

40 Cf. Anatole France: "It seems that the true image of the past has been revealed to us by the great historical school of our own age .... we have created the comparative history of humanity. Fresh sciences such as ethnography, archaeology, and philology had had a great share in doing this .... And this sense of origins, this divination of a lost past, this knowledge of the childhood of humanity, is possessed in the highest degree by M. Renan," in "M. Ernest Renan, Historian of Origins," Of Life \& Letters, 286).

41 Cahiers, 55. 
his little essay on the writings of "great northern writers, Bjornson, Ibsen, Tolstoy, Dostoivesky," ${ }^{2}$ and two versions of the essay "On Religious Faith" 43 that we will deal with at length presently, let us turn for a moment to this rewriting of the response to Renan's dictum. It is virtually the same word for word until the last two paragraphs. These modify what he said on the previous page:

The study of literary history is the domain of criticism, the domain of science; the reading of great works is the domain of sentiment, of the awakening of impressions of beauty of all kinds.

Rather than making the rhetorical balance of subjective/objective, Dreyfus here speaks of science and sentiment, expanding on that last term into impressions of beauty. The contrast is less strong and shades into complementarity, the only problem occurring when Renan draws the contrast himself. For Dreyfus, in the lines he was presumably not satisfied with before and crossed out, the solution is one of trying for a reconciliation, a compromise, a making of peace, and so he withdraws his own denigration of Renan's comment as a boutade, a toss-off line:

One must not see in this idea expressed by this great mind who calls himself Renan only a simple whim [une boutade] at a moment when he himself plunged into the study of pure criticism, into philological studies that totally absorbed him. The study of literary history makes one see the evolution of the human mind and, under this name, it is instructive and interesting.

Although Renan, for reasons of his own, turned his attention in a

42 Cahiers, 54. This determination of northern writers includes Russians and Scandinavians and also Nietzsche from Germany and Switzerland, whom he also mentions, or rather, having pointed out the "humane" quality of the writers mentioned and taken their side against detractors, he slides into a discussion of the importance of putting literature into its context, chronological and geographical, which concern for the "temperament, climate, ambient influences" leads him to watch how the individual escapes from "Cartesian oppression" wherein the mind exists in a purely abstract vacuum, with Nietzsche being a primary example of someone who has "broken from himself."

43 Cahiers, 54-55, Cahier I, F॰8 and Cahier F॰10. 
more strictly philological (scientific) direction, ${ }^{44}$ Dreyfus appreciates the great man's previous openness to the humanist approach to literary studies and explains his own belief in the evolution of the human mind-a mind that grows, changes, and adjusts to its environment, and is not oppressed by the Cartesian split between an abstract inner world and the confused sensations on the outside. What Dreyfus must fight against in his own life are the horrible external tortures, the physical shackles of his exile on Devil's Island, with its loneliness and despair, and the moral disintegration of his own mind, already hypersensitive and now likely to slip into madness through the shame and humiliation of the charges against him. It would be all too easy to plunge himself into a kind of philology, a universe made up only of words that rattle about in a vast and empty space. The important thing to do is to face up to the real problems of the hostile and dangerous world, and to wrestle with them like a good Jew, guided by the ethics of the fathers and the long tradition of questioning and mutual challenging. Neither one nor the other, not withdrawal from reality into sterile intellectualism and not total engagement with pain, humiliation, and suffering, but as

Rabban Gamaliel, the son of Rabbi Judah the Prince, said, An excellent thing is the study of the Torah combined with some worldly occupation, for the labor demanded by them both makes sin to be forgotten. All study of the Torah without work must in the end be futile and become the cause of sin. Let all who are employed with the congregation act with them for Heaven's sake, for then the merit of their fathers sustains them, and their righteousness endures forever. ${ }^{45}$

Intellectual work (Torah in the widest understanding of the term ${ }^{46}$ )

44 For Renan and for Dreyfus, the immediate sense of philology would be the scientific study of literary texts, that is, seeing each as a type produced by the measurable qualities of nationality, race, and economic class, but this kind of avoidance of dealing directly with the imaginative, poetic quality of the texts as works of art would conform to the rabbinical procedures of pilpul, where the immediate contexts, implications, and legal application of the scripture being studied are made subordinate to exegetical acrobatics.

45 Pirqe Avot, 2:2.

46 "The word Torah is left untranslated. It is variously used for the Pentateuch, the scriptures, the Oral Law, as well as for the whole body of religious truth, study and practice," Siddur Sephath Emeth 
and real-world labor (avoda), which is the work both of serving God in liturgical and ritual duties and also earning a living through service to the community, go together to help one forget sin, and through working with society (the congregation) one can draw on the "merit of the fathers" (zekhut avot) and inherit the rewards of piety and ethical life: "All Israel has a portion in the world to come," according to the headnote of the Chapters of the Fathers. So too we hope for Alfred Dreyfus.

But would he have known or cared ${ }^{47}$ In this same cahier, between the two versions of the Renan essay, he writes two versions of an untitled essay I call "Religious Faith." Let us see what he has to say. The difference between the two is not large, but shows how their author is thinking through and refining his ideas. On both folio 8 and folio 10, he begins in the same way with the same words:

\section{Religious Faith}

We need to reduce the question to two essential terms: to choose between determinism and revelation; and this choice is not a matter of reason-it is a question of faith. Against such faith, no criticism prevails; it is admirable and I envy those who possess it...

This is Dreyfus's religious credo and his philosophical position. One either is or is not religious, and that means one is either: a determinist, since some god or other has created the world, limits where one is and what one can do, and thus sets out the basic parameters of life; or one is a rationalist, who sees the world as subject not to an arbitrary will but to laws of nature that can be understood by reason and science and, with that understanding, has the freedom to make adjustments in one's life to secure advantages, subject to the realities of nature. But the type of person one is is not open to a totally free choice; it is a matter of faith, but what he means by foi needs to be found out. To begin with, accord-

(Speech of Truth) Order of Prayers for the Whole Year, Hebrew and English, no editor or translator named (New York: Hebrew Publishing Co. 1953), 229, note.

47 Compare the words of André Maurois, who like Alfred Dreyfus came from a Jewish family of Alsatian manufacturers displaced after 1870, in his autobiography: "To sustain me in this premature crisis of adolescence I had no religious faith whatever. I did not know (and even to-day do not know exactly) the doctrine of the religion which by birth should be mine" (Call No Man Happy, 30). Thanks at least to Lucie and her family, Dreyfus would not have been so ignorant of his own background. 
ing to Dreyfus, placing himself within the large camp of secularists and rationalists of the nineteenth century, but not completely and dogmatically, faith is a frame of mind. He envies those who have it, finds it enviable, and yet cannot will himself by logical argument into its possession. At this point, the two versions of the essay begin to diverge. The first version continues in this way:

But since one doesn't believe, not even as a child, since criticism, the spirit of reason, was melded into me-it is useless to break your head, to get all tipsy with aesthetic reasons, to search in nature, in the universal conscience etc. for reasons to believe-with the affirmations - with the affirmations of reason, of science, leave the dissolution of religions...

Before the syntax breaks down altogether, notice how Dreyfus finds himself unable to follow the various schools of rationalism, idealism, mysticism, and romantic naturalism available around him. He laments the fact that he cannot have faith because he was brought up with too much of a critical sensibility, and he says, speaking more to himself than to any objective imaginary audience, that there is no use getting yourself into a state of confusion through Romantic aesthetics or German idealism or some imperative will to believe, all of which would attempt to break down the structures of organized religion. It would be so much easier to bear his own pains and humiliations if he could believe, but he doesn't and he can't, so why should he pound his head on a brick wall?

In the second little essay on folio 10 , he says something similar but not quite the same:

Against faith, no criticism prevails, and I envy those who posses it. But since one doesn't believe, like a small child, without reason, and true science does not meddle with it-despite the bankruptcy of science-it is useless to break your head, to get all tipsy with a so-called rational aesthetics - to search for it in nature, in the universal consciousness . . . or for reasons to believe in: of an affirmation of reason in science, a kind of dissolution of all religions. 
Once again, he begins by stating that he envies those who have faith, who were born with it, or at least were born into an environment where faith was impressed into their personality. The failure of science and rational philosophy on their own to help him out of his despair exposes their bankruptcy: true science, in fact, steps away from the most important questions of all in life, and consequently, there is no use chasing the phantasm in any form of Rousseau's back-to-nature primitivism or more contemporary pseudomystical aestheticism in search of the egotistical sublime or Hegelian hunt for the universal Time Spirit. ${ }^{48}$ He doesn't see traditional religions as the great enemy, and wants no Voltaire to scream in his ears, "Ecrassez l'infame!"

In both versions, then, Dreyfus wishes he had faith to believe in religion, but he also cries out in pain at the inadequacies of all the apparent alternatives propounded by his favourite authors and the supposed bedrock of his civilization. Therefore, he tries to explore the alternative more closely. In the first essay he writes:

To those who don't believe, reason furnishes a contrary explanation to the phenomenon of belief. God enters the category of the ideal, in the dream that we all share of humanity where all will become noble, good and just. Religion is the beauty in the moral order and that is all. For purely philosophical idealism is only available to the highest intelligences, while purely religious idealism is only accessible to the most humble minds.

This seems to set out a paraphrase of the latest secular, moral religion for the nineteenth century. The old religious systems can be rationalized away as variations on a shared human deism, wherein everything essentially good, noble, just, and tends towards a perfect ideal eventually. God is the ideal of beauty of a moral universe.$^{49}$ But without considering

48 Proust, Finding Time Again: "Dreyfusisme was now integrated into a range of respectable and normal things" (33-34).

49 Benmozegh cites Renan: "Enamored of beauty, nature soars towards her with an unceasing impulse, and approaches closer and closer to her in its forms. The universe is thus an immense being which rises relentlessly toward a higher end which it has prepared though all its previous efforts, proving at once its enormous desire for the good and its marvelous ingenuity," and adds that in Kabbalah, this concept is carried out in a way that makes the enhancement of natural beauty come about 
the absurdity of such time- and culture-bound categories of thought, Dreyfus sees their weakness in the social limitations they enforce: one must be rich and comfortable, well educated, and arrogant to believe in the ideals, but the primitive and poor, the uneducated and unsophisticated alone have access, not to a lesser faith or set of popular superstitions, but to religious idealism - to the longed-for faith of other times and other places. ${ }^{50}$ In a sense, Dreyfus mocks both science and religion as failed ideals and at the same time regrets that he cannot have faith in either.

He makes this even clearer in the second version of the essay On Religious Faith:

To those who don't believe, however, reason furnishes an explanation of the phenomenon of all beliefs, the innate need in all beings to come out of brutal realities, of plunging oneself into the domain of dreams, of the ideal, of a humanity which will be supremely beautiful, noble and just. A religion whichever it may be, is the beauty of the moral order, that is all. For a purely philosophical idealism is not intended for use by all intelligences, while the purely religious idealism is meant for more humble spirits.

The modern authors, such as Michelet, Renan, and Taine, whom

through man's intimate participation in the creative processes themselves, through nourishment, sexuality, and performance of the mitzvot (Benmozegh, Israel and Humanity, 188).

50 Faur: 'superstititon' and 'superstitious' are terms associated with 'dread and belief in the irrational.' In the original Latin, however, superstito and superstitious had a different meaning. 'Superstition' was knowledge of a past event, and 'superstitiosus' was that individual who had the peculiar gift to 'testify' about an event in which he was not present" (The Horizontal Society, Section IV, Introductory Remarks). We could go further in this etymological game that opens up whole new ways of breaking into the hidden meanings of Dreyfus's text. For instance, to testify was a legal term related to to theorize, which described the particular mission of delegated representatives of one city state (polis) to visit, participate in, and report back on the power of another city's rituals; hence, it was the special ability to bring home a charged testimony a speech filled with enargaeia that infused the home state with the "truths" of their enemies or rivals. Dreyfus looks backwards to his life before he was charged with crimes and foreward to the day he will be rehabilitated, regaining his name and honor, and the purity of soul for himself and his family, that is all important to his sense of self and identity. His critical readings and commentaries give him a theoretical power to testify to his own innocence. $\mathrm{Cp}$. discussions of melitza throughout this book. 
Dreyfus reads intensely, or those writing at around this very time, such as Freud and the Reinach brothers, whom he as yet does not know about, offer ways of rationalizing revealed religions based on faith; of explaining away mysteriousness and spirituality by recourse to analysis of dreams, myths, and archaic rituals; and of smoothing away all the specificities of different times and cultures in order to envisage a utopian ideology of one sort or another, and it all depends on class and other circumstances to determine in which category of belief you fall.

Then, at this point in both versions of the essay, he makes his formal statement of belief. In the first he writes:

I am neither a believer not hostile to belief-I am a sympathetic witness, on the contrary, to those who believe, since I am conscious of the moral good of those who do believe, on condition always that this belief does not become a narrow idea, an abstract formula, or that reduces itself to an airy idealism. In conclusion, philosophical idealism for high intelligences, religious idealism for humble minds: this is what will become of the summing up of the beauty and the moral good in our beliefs.

Is Dreyfus, then, an agnostic or an atheist or merely confused and despondent? He seems to want to take a neutral stand, neither for nor against religion per se, inclined by disposition towards science and rationalism but all too aware of their inadequacies to deal with the situation he is in or the surging sense of meaninglessness in his life. He observes from afar, a not quite dispassionate witness to those with faith who can find the moral strength to withstand the forces of oppression and evil in the world, who can, as he seems unable to, understand the conspiracy of arrogance ranged against him. He ought, by his own calculations, to belong to the superior intellects who can be satisfied-find a consolation of philosophy-in the higher ideals; he wishes he could have a simpler faith, perhaps like those of women and children or of his rabbinical ancestors.

The second version of this final statement follows exactly the words of the first, until the final sentence, where it diverges with a subtle new expression: 
In conclusion, philosophical idealism for high intelligences, religious idealism for humble spirits; this is what we should reduce beauty and moral good in our beliefs.

It is the difference between "à quoi devraient se resumer" and "à quoi doivent se reduire," between what should be summed up into a belief system and what must be reduced into that desired system of beliefs. In the first, there is a sense of fulfilling a future duty and collecting together of diverse ideas; in the second, a subjunctive hope and speculative doubt about the consequences of reducing the diverse ideas into one faith.

On folio 10, after those last words shared with the first essay, Dreyfus draws a line across the manuscript and adds nine of his doodles. He then writes:

Human thought in all its power, in all its [illegible word] can only use that force with a moral value which is imprinted, or else it is as abstract and as dry as a mathematical problem can be [illegible word]. ${ }^{51}$

If not conceived as a part of the essay on faith, these lines supplement it in a striking if ambiguous and frustrating way. The two unreadable words in the manuscript prevent any complete understanding of what it is that Dreyfus wishes to say here. Just as he argued that a person cannot reason his way into faith if he has been brought up to be critical and believe in science, even after he has realized that rationalism itself and science are inadequate to provide him with consolation or a way of understanding the horrible ordeal he is going through, just so la pensée humaine with all its puissance can only achieve its ends by the moral value (la valeur morale) it has imprinted (est empreinte) in it-but what

51 Compare the words of Max Nordau, as he ironically and scathingly excoriates the French attitude towards Jews: "I must utter the painful word. The nations which emancipated the Jews have mistaken their own feelings. In order to produce its full effect, emancipation should first have been completed in sentiment before it was declared law. But this was not the case .... The emancipation of the Jews was not the consequence of the conviction that grave injury had been done to a race, that it has been treated most terribly, and it was time to atone for the injustice of a thousand years; it was solely the result of the geometrical mode of thought of French rationalism of the $18^{\text {th }}$ century. This rationalism was constructed by the aid of pure logic, without taking into account livings sentiments and the principles of the certainty of mathematical action; and it insisted upon trying to introduce these creations of pure intellect into the world of reality." Nordau, "Address at the First Zionist Congress" (1897), MidEastWeb. 
the additional quality in such thoughts is that makes it effective we can only guess. Without that power of moral suasion, however it is come by, reason by itself is as dry and abstract as the mathematical equations Dreyfus scribbles up and down his pages, along with the obsessive little drawings.

Nothing explicit, it seems, is said about Judaism in either of these essays. Nor, it would seem, about Christianity, since the debate in his mind is between scientific rationalism and a kind of poetic, philosophical religion on the other. It may be that Dreyfus has couched his terms in a vague, occluded language that recalls Maimonides in his lengthy instructions to his pupil, The Guide of the Perplexed, in which someone who has trained himself in Greek knowledge-philosophy and mathematics, for the most part-finds himself perplexed by the mythical and mysterious language of the revealed scriptures, as well as by the crabbed, oblique midrashic style of the rabbis. The Rambam does not aim to enforce a faith on his student, to force a dogmatic interpretation on that divine text, or to reject reason and science; instead, he teaches, in his own midrashic style, with all its mixture of tones, its fragmentation and seemingly disordered presentation of the argument, how to read the sacred books so that they conform to Aristotelian principles of logic, grammar, and science.

On folio 12 of the first cahier, ${ }^{52}$ Dreyfus then offers a critical reading of Tolstoy. It will be of interest, in light of his statements about religion and science, to see what Dreyfus has to say about The Gospels Translated, Compared, and Harmonised, which was published in Russian between 1880 and 1882 and translated by Wizewa and G. Art. He begins by paraphrasing what these two translators say in their introductory remarks, noting that the Russian thinker is using his study of the New Testament to advance his own "new Christianity." For them, this innovative reading is peculiar.

The translators find that Tolstoy is at home in the sacred text. Discourse and parable, thought and imagery, all are taken in a new sense.

But then, as so often happens, Dreyfus intrudes into the paraphrase 
to speak in his own voice, to raise his own objections to what Wizewa and Art have written, and to question Tolstoy's ideas as well.

This should not astonish us. The text of the Four Gospels are not in agreement in all interpretations!

Dreyfus takes a sceptical position in regard to these Christian documents, establishing first of all that the Four Gospels do not agree with one another and that they are a composite of diverse kinds of discourse whose meanings interpreters have not agreed on. If Tolstoy offers a unique approach to interpretation, Dreyfus is not surprised: everyone in rabbinical tradition, and certainly anyone who has read or heard of Maimonides, should be prepared to see in discourse, parable, thought, and imagery a dynamic and multilayered textuality; this category naturally includes the Gospels. ${ }^{53}$

The two translators of Tolstoy express another surprise, that the Russian, "having proclaimed the divinity of Jesus's doctrine, refuses then to recognize the divinity of his person." For Dreyfus, that in itself seems a rational distinction, the revealed word having a divine nature that does not necessarily pass on to the deliverer of the Word, as with the law given to Moses on Sinai and Moses himself who is always a man, albeit the best of the prophets. What surprises Dreyfus, in the sense that his own Jewish sensibilities cannot follow Wizewa and Art in their Christian faith, is that "Tolstoy is simply incomplete" because "neither the person nor the doctrines are divine, they are simply human." This is the position of a nineteenth-century secular, assimilated Jew, and one that he shares with many secularised Christians of his day, whether they call themselves atheists, agnostics, or nothing at all.

In the final sentences of this brief critical essay, Dreyfus becomes more complex and more obscure to us-because he has crossed out too much and his handwriting becomes undecipherable to the modern editors:

It would have been better for the translators to grasp simply these words [illegible word] of Alexandria, that

53 Marcel Mergui and his Champs du Midrash group will be discussed later. One of their most interesting characteristics, as they seek to explain Christian scriptures as the result of primitive misunderstandings of Hebrew midrashim as the core of Gospel thinking, is that they stress the visualized midrash in iconography and art. 
it was not so well to examine all the matters of religion, that it would be better for each one of us to remain in his own beliefs. [This whole text has been crossed out.]

Which writer of Antiquity he refers to is not clear, but the import of his statement is, let everyone remain in the beliefs he was born to and make the best of it, since conversion under duress or in crisis means nothing, and those who did become something new, presumably Christian, have not really benefited. In a way, this accords with Dreyfus's own statement of tolerance and envy of anyone with a true belief, any departure from what one grew up into being a form of drunken lurch.

Then, with the passage obliterated, in place of the rejected text, Dreyfus draws a horizontal line, and writes, "Let us enter this subject"-and nothing follows but a drawing of two hyperbolas and a long series of numerical equations. Hopefully, these mathematical games are not the dry and abstract formulation of another inadequate state of mind.

From now on, rather than attempting to give a close reading of each of Dreyfus's critical or speculative essays, ${ }^{54}$ we shall only focus on a few that demonstrate some special feature in his personality or situation that breaks through the surface of the text. But first a brief interlude and series of digressions.

\section{Dreyfus's Doodles, Iconography, and Kabbalistic Signs}

That is what Bacon called the principle of our eternal ignorance, the ignorance to which the conditions of man condemns us, walled in as we are within a rock, solitary and deceived in the midst of the world.

-Anatole France ${ }^{55}$

In the various studies of Dreyfus's drawings in French, the common term used for them is dessins, drawings, sketches, or designs, there apparently being no French equivalent to the English word doodle. ${ }^{56}$ To

54 In a future book, we will deal more extensively with Dreyfus's readings, tastes, and opinions in matters of literature, historiography, culture and science.

55 France, "Goerge Sand," On Life \& Letters, I, 300.

56 It is possible that folk-etymology projects back into "doodle" some of the qualities associated with a similar-sounding word dawdle, to linger, to temporize, to wander about aimlessly. 
speak of these line drawings as scribbles or scratchings misses the point of the nonverbal quality of the work. Another French word, gaspiller, comes to mind, in that it matches with the etymological root of doodle (to play on a "doodle-fife" or bagpipe and hence to make annoying, tedious, and meaningless sounds or, by metaphoric extension, to make obsessive, pointless, empty drawings while listening or speaking to someone else), but if the closest French equivalent to doodling is gaspillage, in the sense of wasting time, squandering energy, and lavishing effort better spent on something important, it seems never to have been used in regard to Alfred's drawing.

Although many (though hardly all) of the drawings begin with an $\mathrm{X}$ (or aleph $\mathrm{N}$ ) or a $\mathrm{Y}$ (or tsadeh $\mathrm{\gamma}$ ), these do not serve as letters or abbreviations for words. They might be compared to the bizarre imagery to be found in Glozel, and the connections between the whole Dreyfus Affair and this controversial archaeological site in central France, near Vichy, may be seen both in terms of the actual objects collected between 1924 and 1932 and the newspaper articles, scientific studies, and popular imagination that swirled about in what came to be known as the War of the Bricks or the Second Dreyfus Affair. A key figure connecting the two affairs is Salomon Reinach, a strong Dreyfusard in the 1890s and a major supporter of the legitimacy and importance of Glozel during the 1920s.

It is also possible to see in these drawings a kind of childish game, such as Elias Canetti imagines in his early memories when he saw people inside the wallpaper designs of his bedroom, but in regard to Alfred's doodles, we could rather see projections of his anxieties, fears, desires, and hallucinations caused by isolation, sensory deprivation, and illness. They might be nightmare images, distortions of the once-familiar faces, flowers, and buildings he is now deprived of.

The constant iteration of these pictures, each one drawn to a basic $\mathrm{X} / \mathrm{N}$ or $\mathrm{Y} / \mathrm{\gamma}$ pattern with endless variations of efflorescence of curvilinear designs, may also suggest a kind of series of animated cartoons, not in the sense of comic strips or books, with either satiric or heroic purpose, but rather a manifestation of the need Dreyfus felt to make order out of his disorderly life, to find the mobility his incarceration denied to him, and to generate a kind of free creativity otherwise impossible in the circumstances in which he found himself.

The prison guards assigned to watch all of Dreyfus's activities and to collect and either recopy them or write a report on their contents 
described the doodles in three ways: sometimes they called them architectural shapes, and we now know that in the missing cahiers, there may have been some transitional movement away from the cones and other geometrical drawings, along with shaded outlines of various structures that could well be construed as "architectural." At other times, they called them "desseins cabbalistiques" by which they probably meant nothing more than tediously, esoterically, and exotically Semitic, without seeing any specific secret significance in them. To them Kabbalah might not even have alluded to any historical school of medieval or Renaissance mystical traditions. If it did, then they would surely have sought expert advice, even if perversely anti-Semitic, since the constant surveillance of the prisoner's behaviour and the censorship of his writings was meant precisely to uncover evidence of any treasonous intentions, such as clues as to his non-French, that is, Jewish, tendencies and attitudes or beliefs. ${ }^{57}$

On a very few occasions, the scrutinizing guards recorded the doodles as not only kabbalistic but as "desseins cabbalistiques ordinaires," this second adjective suggesting either some further knowledge they had obtained or subtle inferences they were making as to a particular system of Jewish conspiratorial system or code, with ordinaires pointing towards an official, regular purpose in the drawings.

But while again it is likely that the government agents assigned to check up on the deportee's secret thoughts and feelings did not really have anything more in mind here than a vague allusion to the kind of absurdities contained in The Protocols of the Elders of Zion or at least spoken of in irrational terms by anti-Semites such as Edouard Drumont, the argument made in this book is that we cannot dismiss the nonsense of the Jew-haters out of hand because this nonsense forms the matrix of the affair and of the society of irrationality in which the Holocaust would crystallize over the subsequent half-century. In other words, here as in other places, these anti-Semites did not merely misinterpret Jewish practices, traditions, and beliefs. They did see and feel something

57 As a matter of fact, while at this same period the School of Jewish Science (Jüdisscheswissenschaft) in Germany was spreading amongst rationalist reformers in France and other progressive countries, there was a countervailing body of opinion, usually centered around Sephardic and Italian rabbis, such as Elijah Benmozegh, who would argue that in many, though hardly all, instances that Kabbalah "is a faithful exponent of rabbinic thought" (Benmozegh, Israel and Humanity, 188). 
that academic historians of the affair then and now overlook, much as they fail to recognize certain aspects of the whole crazy conspiracy of arrogance. The central characters in the affair, such as Dreyfus himself and his closest supporters always tried to deny the anti-Semitism out there, and the Jewishness in the prison writings and the letters, as if the noise in the streets and the slurs in the press meant nothing. One has only to look at the writings of Marcel Proust to see how deeply the feelings and prejudiced thoughts of anti-Semitism went in French society during the whole period of the affair and afterwards, when people forgot what they had been so excited about. ${ }^{58}$

\section{Instruments for Hearing, Seeing, Thinking, and Feeling}

However, for religious reasons the idea was conceived by the Ashkenazic rabbis, to express the significance of every holy day by distinctive tunes, and to consecrate special melodies to each occasion in order to create the distinctive atmosphere for that day. ... Upon entering the house of worship on one of these days, the Jew was inspired by the dominating mode or melody which reminded him of the purpose of the day.

-A. Z. Idelsohn ${ }^{59}$

According to the Belgian artist Emile Verhaeren, what distinguished the Parisian art scene at the end of the nineteenth century was its seething diversity of schools of painters, groups which were, he says, forever dividing up, regrouping, and splitting again. ${ }^{60}$ In a sense, this might also be a way of describing the political dynamics in the capital of France, and Paris was, as many come to think of it now, the capital of the nineteenth century in many other ways. But these competing, hostile and coalescing factions were not so much unstable and incoherent, that is, chaotic or anarchic, random or mindless, as they were exploratory and

58 Proust, Finding Time Again: "For the rest, to conclude the topic of the duchesses who now frequented mme Verdurin's, they came there, though this never occurred to them, in search of exactly the same thing as the Dreyfusards had once done, that is to say a social pleasure constituted in such a way that its enjoyment both assuaged political curiosity and satisfied the need to discuss among themselves the incidents they read about in the newspapers" (37).

59 Idelsohn, Jewish Music, 134-135.

60 Cited in Ingo F. Walther and Rasiner Metzger, Van Gogh: The Complete Paintings (Koln, London, etc.: Taschen, 2006 (original German edition 1990), 272. 
creative. Thus, Verhaeren goes on to say

The diverse tendencies remind one of movable geometrical patterns, as in a kaleidoscope, one moment opposed and the next united, merging then separating again, and then crumbling, but nonetheless moving within a constant circle, that of modern art. ${ }^{61}$

It will pay to look more closely at this metaphor and then to explore its implications in regard to two other complex conceits that I use in this book to try to see and understand Alfred Dreyfus and the Dreyfus Affair-and use more than as just a touchstone by which to measure and test the constituency of its elements, but much more as a whetstone to sharpen our comprehension of what was going on in the minds of involved individuals and groups and their milieu; as well as a lens.

The word kaleidoscope came into use in French on the model of the term invented by Sir David Brewster in 1817, built on the Greek roots kalos (beauty), eidor (aspect or form), and skopein (to see), to denominate a long tube, like a microscope or telescope, but with a lens through which are seen, against a background of curved or angular mirrors, an array of small pieces of coloured glass or beads; when the tube is rotated, the particles of tinted glass are reflected and refracted in the mirrors as ever-changing symmetrical patterns. Although it was quickly popularized as a toy for children or a device for adult entertainment, with the kaleidoscope Brewster was seriously working in the investigation of polarized light, and he imagined uses for architects, painters, jewellers, and other craftsmen seeking new design patterns and colour combinations. According to the specifications in his patent document,

The kaleidoscope . . . is an instrument for creating and exhibiting an infinite variety of beautiful forms, and is constructed in such a manner as either to please the eye by an ever-varying succession of splendid tints and symmetrical forms, or to enable the observer to render permanent such as may appear most appropriate for any of 
the numerous branches of the ornamental arts. ${ }^{62}$

Before it became either a mere toy or an interesting metaphor in aesthetic discourse, Brewster was thinking,

if any object, however ugly or irregular in itself, is placed before the aperture ... the part that can be seen though the aperture will be seen also in every sector, and every image of the object will be seen also in every sector, and every image of the object will coalesce into a form mathematically symmetrical and highly pleasing to the eye. If the object is put in motion, the combination of images will likewise be put in motion, and new forms perfectly different but equally symmetrical will successively present themselves, sometimes vanishing in the center, sometimes emerging from it, and sometimes playing around in double and opposite oscillations.

Thus, more than the Newtonian prism used to break up a ray of light into its constituent rainbow of colours, the kaleidoscope now creates new forms, tints, and-this is very important as a forerunner of animated motion pictures-movements. This way of thinking about the nature of sight and what can be done to create various illusions sought, by the play of mirrors and lenses, to foreshadow developments in painting and other arts that eventually come into focus under the names of impressionism, post-impressionism, cubism, fauvism, and so forth.

In regard to the mysterious designs or doodles that fill whole folios and the empty spaces on pages in Dreyfus's workbooks from Devil's Island, we can perhaps suggest that he is himself playing with configurations of light, lines, space, and movement. As we have already discussed in reference to Taine's theories of intelligence and Tarde's notions of imitation as the driving force of social behaviour and collective thought, the scientific ambit of Brewster's new invention takes part in the impetus of the nineteenth century's break with the previous age's rationality and classical concept of symmetry. 
The partial polarization of the light by successive reflexions occasions a partial analysis of the transmitted light; but in order to develop the tints with brilliancy, the analysis of the light must precede its admission into the aperture. Instead of looking thro' the extremity . . . of the tube, the effects which have been described may be exhibited to many persons at once, upon the principle of the solar microscope or magic lanthorn, and in this way, or by the application of the camera lucida, the figures may be accurately delineated.

Significantly, as a metaphoric reference point, this instrument does not introduce new materials or colours but generates new combinations and patterns and hence new responses in the viewer's eyes. It moves into a realm of dynamic, moving imagery and perceptions that can be shared between many viewers, thus creating collective experiences of polarized light shows and illusionary visions of nonnatural phenomena. Moreover, in his final comments in the patent document, Brewster sees a further application which would correct the faults in previous attempts to visualize sound:

When Custillon proposed the construction of an ocular harpsichord, he was mistaken in supposing that any combination of harmonic colours could afford the pleasure to the person who viewed them, for it is only when these colours are connected with regular and beautiful forms that the eye is gratified by the combination. The kaleidoscope, therefore, seems to realize the idea of an ocular harpsichord.

This ideal of a mechanized synesthesia looks forward, not so much to the realistic or documentary style of motion pictures ("talkies") that someone like Proust objected to on the ground that it would limit the imaginative play of the eye on reality that is the essence of poetic creation, but rather to the kind of fantasia and phantasmagoria filmed by Georges Méliès-including coordinated speaking and music-at the time of the Dreyfus Affair.

It was an advance on the many optical instruments invented during 
the preceding century and would culminate in the 1890s with what we now call motion pictures. To understand the metaphorical and rhetorical uses we are putting together in this book on Dreyfus, then, we need to be aware of the shifts in imagination that were occurring during his lifetime. ${ }^{63}$ Whether he had ever attended an entertainment or scientific performance involving these fantasy-producing machines is not more relevant, in a sense, than whether he attended an art exhibition or visited museums such as the Louvre in Paris displaying works from the various impressionistic and post-impressionistic schools during this period of the late nineteenth century. What is relevant is that these transformations in perceptual and aesthetic mentality were happening around him and that he himself shows an interest in the psychological, scientific, and aesthetic ideas that were driving these developments.

The phantasmagoria, which we have alluded to several times in earlier chapters, was developed in France during the period of the Great Revolution and thus at about the same time as the kaleidoscope. Rather than a single instrument, the phantasmagoria was often a sustained, lengthy, and complex performance using optical projections, music and auditory effects, as well as tactile and olfactory elements. It was part of the popular entertainment industry that grew up in Western Europe over the nineteenth century, sometimes in ad hoc street performances and sometimes in fairgrounds, circuses, and theatres of magic and illusion, and then on film. But there are two other manifestations of the phantasmagoria that we need to look at in order to understand how it can help us understand the Dreyfus Affair, this frenzied obsession that tore at the heart of France for at least seven long years. ${ }^{64}$

One is the way, partly touched upon earlier, in which, following Taine's psychological discussions of intelligence, the double and triple play of simulacra and memory images form themselves into what is

63 In Bourget's discussion of Flaubert's imagination, a discussion Dreyfus shows that he read, there are two forms of this mental faculty and thus two constitutive collections of images registered from experience and created in the mind from the interplay of the individual's own cognitive processes. Unlike Taine, but more like Proust and Flaubert, as Bourget indicates, Dreyfus saw the spirit of man engaged in a dynamic dialectic, constantly making and unmaking himself and struggling against deterministic tendencies in society and nature; cf. Bourget, Essais de psychologie contemporaine, 165-167.

64 Romain Rolland: "Both man and wife had been bowled over by the storm of the Dreyfus affair: both of them had taken the affair passionately to heart, and, like thousands of French people, they had suffered from the frenzy brought on by the turbulent wind of that exalted fit of hysteria which lasted for seven years" (Jean Christophe, Vol. II, 340). 
called an inner phantasmagoria of the mind. The other, apparently limited to the period of the Revolution and the First Empire, is how tacticians and strategic operators projected spectral images into foggy night battles in order to disorient, frighten, and cause panic in the enemy; such a practical military usage suggests, moreover, that the devices developed by magicians and theatrical entertainers for popular audiences were available for propagandistic purposes - a kind of manipulation of crowds into mass trances that culminated in Nazi rallies in Nuremberg during the 1930 s. $^{65}$

\section{Zekhut}

All Israel have a portion in the world to come, as it said (Isaiah lx.21). And thy people shall be righteous; they shall inherit the land for ever, the branch of my planting, the work of my hands, that I may be glorified.

-Pirqe Avot

It has already been mentioned several times that one of the underlying secret principles behind Dreyfus's self-concept as a Jew was that of intergenerational merit. ${ }^{66}$ This idea of zekhut was surely one of the most revolutionary ideas in the development of rabbinical Judaism after the fall of Jerusalem and the end of Jewish autonomy in the Land of Israel, after the destruction of the Temple and the impossibility of maintaining the cult of sacrifices by priests and Levites, and after the burning of the morasha or National Archives, where the statutes of the law were kept. Before the fourth century CE, zekhut usually had a simple meaning "merit" or "reward." Individuals, usually the famous forefathers and foremothers of Israel, performed meritorious deeds. Abraham, Isaac, Jacob, Moses, Sarah, Rebecca, Leah, Rachel, and Ruth, as well as many others, were included in this group. They were all honoured by Israel and by God for their great acts of generosity, goodness, bravery, and daring. They were remembered for their goodness, and the rest of Israel could remember them with pleasure and pride, and thus, because God also shared these

65 Further discussion on this and related matter will appear in the next volume of this series.

66 Jacob Neusner, Theological and Philosophical Premises of Judaism (Boston, MA: Academic Studies Press, 2008); this is my primary authority on the concept and history of zekhut. Other authorities will be brought in later in this book. 
feelings of pleasure and pride, all of Israel could feel close to God.

But the radical shift in meaning and usage of zekhut was quite different, shockingly so. ${ }^{67}$ In the first place, as Jacob Neusner points out, "the Mishnah's philosophers reject prophetic and charismatic authority and deem critical authority exercised by the sage's disciple who has been carefully nurtured in rules, not in gifts of the spirit,"68 but also that the heavenly court gives its judgements and favours on the status of the whole community and is therefore not the sole determining authority; indeed, one is the concomitant of the other, forming "a single system of power." ${ }^{69}$ Without the mediation of the temple, where the priestly cult of atonement sacrifices took place, the rabbinical courts could call on heavenly power to supplement or replace their own through submission. This submission takes the place of charismatic or heroic deeds, precisely because it involves acts that involve what the covenantal law grants to each individual and which God cannot demand from him or her-free will, life, and love of family and self. As Neusner puts it,
What we cannot accomplish through coercion, we can achieve through submission. God will do for us what we cannot do for ourselves, when we do for God what God cannot make us do. In a wholly concrete and tangible sense, love God with all the heart, the soul, the might, we have. ${ }^{70}$

Thus, not only did the great men and women, our forefathers and foremothers of blessed memory, gain spiritual merits that have been

67 One of the translations offered for zekhut is the Christian term supererogation, where it refers to the overflowing of grace attained by Jesus on behalf of sinners and saints whose individual and collective good works are not sufficient for salvation. Using this term as a heading for his tale, S. Felix Mendelssohn recalls that "[d]uring the High Holiday services in a Brownsville Synagogue [a suburb of New York City] a bearded young man chanted the introductory prayers. When the services were over an elderly gentleman walked up to the young fellow and congratulated him, 'May I ask how much you are being paid for your services?' 'Nothing at all,' replied the young man, 'This represents my contribution to the congregation.' The other thought a moment and said: 'That's very nice of you. If one is unable and is yet a willing contributor, his conduct is certainly praiseworthy"' (The Jew Laughs, 180). The joke works on the disguised insult of the old gentlemen (damning the younger with faint praise) and exposing a moral truth (that even a faulty public prayer well-intended earns merit in the world to come).

68 Neusner, Theological Premises, 167.

69 Neusner, Theological Premises, 168.

70 Neusner, Theological Premises, 176. 
credited in the national heritage-often in the sense of honour and sometimes material or political rewards-for their heroic acts, but now the post-Fall rabbis began to teach that this zekhut is stored up in such an overwhelming abundance that God, when he remembers their good deeds, would reward their children's children, all of Israel, even if the people of today are unable to carry out the mitzvot. God's grace and love would come to all men and women just because they were Jews, even if, because of the terrible circumstances they lived in, they could neither perform meritorious deeds nor remain Jews and had converted against their will. So on the one hand, this new concept of zekhut constructed a cosmos in which Israel had inherited a vast stock of former merits and God would distribute them wherever they were needed. On the other hand, zekhut was something that ordinary individuals could earn for themselves and for their families; one need not be a priest, a patriarch, a prophet, a king, or a hero. Neusner then makes an even more astounding claim:

It must follow that zekhut, not Torah, in a single word defines the generative myth, the critical symbol of the Judaism in the documents of which that symbol figures. A single case amplifies the claim that ordinary folk, not disciples of sages, have access to zekhut entirely outside of study of the Torah. In stories told about the rabbis, a single remarkable deed, exemplary for its deep humanity, sufficed to win for an ordinary person the zekhut - "the heritage of virtue and its consequent entitlements" - that elicits the same marks of supernatural favour enjoyed by some rabbis on account of their lifelong, perpetual Torah-study. ${ }^{71}$

In other words, this new kind of meritorious deed was precisely the sort of action, whether active or passive, that God could never force a person to do; it was not among the commandments or mitzvot already mandated by scriptures as part of the original covenant between God and Israel. Above all the God of Israel, blessed be He, could not interfere with an individual's free will, for that freedom of conscience is the one 
lasting aspect of humanity that each one of us possesses-and shares in a profound universal way-with the deity; it is what makes us fundamentally created in the image, the tzelem of God: like the Holy One Himself, we each have free will, moral choice, a determination outside of all prescribed formulations of the law. Who and what we are is not determined by arbitrary rules or laws: we are who and what we are to a limited degree because of our parents and the education they give us, just as we are shaped by the evolution of our species and the geography and environment in which we are born and developed.

But these aspects of our existence, while they can condition what we experience in life, do not determine how we think or feel or see the world. Thus, the God of the Covenant could not ask a father to sacrifice his son or a son to sacrifice himself for his father, or a mother to give her last piece of bread to her son or daughter, or a person to help a stranger at the cost of his own well-being or life. But in the new interpretation of Jewish tradition and writings that developed at the time when Israel went into the world outside of the Holy Land without a priesthood or a temple to perform sacrifices, without a national territory under its control, and without an assured legal right to believe whatever it wished, the new dispersed people needed an ideology or a myth or a faith to live as a nation in exile. What Israel could not do for itself had to be done in another way, so that the accumulated merits of the ancestors could be put into effect in extreme circumstances.

These kind of ethical acts, often secret, usually very humble, always private and probably painful to perform, earned zekhut - rewards in the form of rain on a parched field, recovery of an infant after a horrid illness, relief from taxes in hard years, a sense of meaningfulness in an otherwise empty or evil world. Note that the people who are singled out for zekhut now are neither the priests, kings, or prophets of Israel nor the great rabbinical scholars of the Talmudic Age but rather simple, lowly folk. They are ordinary men and women, like Alfred and Lucie Dreyfus, and by their submission to their ordeal on behalf of truth and justice, not by any specific religious acts or Talmudic knowledge, they draw on the heritage of Israel and gain a portion in the world to come.

Zekhut was, when the new belief system began to develop in the centuries following the churban (destruction) of $70 \mathrm{CE}$, a revolutionary epistemological response to the unexpected and shocking rise of Christianity as a rival religion, one that, having assumed the powers 
of the Roman Empire, challenged the very existence of Judaism in late Antiquity. It was an extraordinary and unexpected mythical answer to the myth of a Father-God who sends His only begotten Son to earth to give His life on the cross for the sake of all who believe in Him. In the Christian soteriological narrative, no individual, by himself or collectively, can effect this salvation, whether by works or faith. Saints and martyrs can imitate Christ and win salvation only because Jesus had already done it, their lives reducing their individuality and condensing their historical specificity to the sacred imitatio christi. Faith and good works, depending on the mode of Christianity, flow from God's grace, and only those who accept Jesus as their Messiah are entitled to these gifts earned by the Saviour.

In the rabbinical concept of zekhut, however, Israel collectively in the past and individually in the present creates the signs of merit that stir God's heart, remind Him of His obligations under the covenant, and cause Him to pour forth His favours-but always in small, oblique, and unspectacular ways. World and national history do not change, but individual lives are experienced in different ways, experienced as midrashic assuagement, correctives, and consolations. Faith or belief is moreover not the determinant value: deeds that were outside the range of Jewish law and Roman censorship and were often unperceived by both the Gentile and Jewish communities were what counted most. To the individual who felt he or she could not endure another moment of history's pain and humiliation, there came a moment of peace and rest, a small relief from agony and despair. So it seemed that there was order, so there was justice in the world, and there was a law still operative, but the law no longer needed a cult centre, a national government, or a body of esoteric rabbinical knowledge.

Were the answers to the two major crises at the formative period of Rabbinic or Talmudic Judaism still relevant in France at the time of the Dreyfus Affair? And were they pertinent to the specific historical case of Alfred and Lucie Dreyfus? Yes, I think, but not because they can be seen directly in the circumstances the Dreyfus family and other Jews were put through for close to two decades-and which closed with only an illusion of respite or resolution. The Great War that followed in 1914 and the rise of Nazism in the 1930s and the Holocaust of the 1940s showed that the dominant negative forces of history had been grinding on relentlessly, even after Alfred was pardoned and seemed to regain 
his honour. The false security of the Jewish community in nineteenthcentury France came to an end. The fervent belief in the principles of the Enlightenment and the Republic proved fatuous. Besides, just as there were already other forms of Judaism at the time of the fall of the temple and Jerusalem-among the followers of Philo Judeus in Alexandria or Flavius Josephus in Rome, for instance, and the writers of the Book of Jubilees or the book of Esther-and different alternatives would be developed throughout the later ages, such as various Kabbalot, the Haskallah, and secularised philosophies, as with Spinoza, so too, as Dreyfus saw, there were alternatives in reason and science or in poetic idealism and primitivist mysticism. But these alternatives could not be sustained in the face of what the state could do to all individuals, and especially to the Jewish people. In the letters he and his wife wrote, as in his prison notebooks, the Dreyfuses endured moral and physical tortures and in the process created something new for themselvesthrough these writings, minor as they are in regard to world literature or history, they created a new kind of love and a new kind of loyalty, a new kind of intellectual critique, and a new kind of poetry. ${ }^{72}$ Thus, Neusner's comments strike to the heart of the matter of how to read and evaluate the letters between husband and wife and their powerful love of family and the prison workbooks filled by Alfred Dreyfus with an abundance of topics from science to art, mathematics to literature, and philosophy and psychology:

Zekhut integrates what has been differentiated. It holds together learning, virtue, and supernatural standing, by explaining how Torah-study transforms the learning man. Hierarchical classification, with its demonstration of the upward-reaching unity of all being, gives way to a different, and more compelling proposition: the unity of all being written within the heritage of zekhut, to be attained equally and without differentiation in all the

72 My own temptation is to spend hundreds of pages in close reading and discussion of all the topics in the cahiers, but that sort of extensive analysis must be put off to the next book in this series on Dreyfus, tentatively entitled Alfred Dreyfus: Essayist, Historian, Poet and Jew. From now on I will begin to deal only with a few of the topics, choosing those in which long-lost aspects of his personality and character reach the surface, obliquely in other people's words and images or explicitly in cries of agony. 
principal parts of the social order. The definition of zekhut therefore carries us to the heart of the integrating and integrated religious system of Judaism. ${ }^{73}$

\section{PART 2: MORE ESSAYS AND EXCURSIONS}

Ils perçoivent les choses et non les idées des choses. . . ${ }^{74} \mathrm{Un}$ esprit se trompe. Un esprit ignore-Jamais une machine à penser. ${ }^{75}$

-Paul Bourget

The fragmentariness or distortion of the human image in Jewish art is in effect not a reduction but an expansion of the human form. The negative commandment prohibiting the depiction of the complete man is in substance a positive commandment to introduce the human spirit into the human form. In short, the slashed nose is the symbol of the soul.

—Steven S. Schwarzchild ${ }^{76}$

It is time now to turn back to the intellectual excursions in the prison workbooks from Devil's Island. After leaving his discussion of a new translation of Tolstoy's book on the Gospels, wherein he took issue with the comments of the translators on the need to focus on the odd ways the Russian idealist had dealt with the modes of narrating, appropriateness of genres, mixing of styles and other peculiarities of presentation, without actually drawing his analogies to Maimonides, Dreyfus leaves off by asserting his unstated Jewish scepticism and rejection of the sanctity either of the New Testament or of Jesus. The first cahier continues for a while then with fragments of letters begun to Lucie, with

73 Neusner, Theological Premises, 183.

74 Bourget, Outre-Mer, I, 87. Although he is talking about the new mind of Americans created in their vast and open land, the thought can be recontextualized to the situation of Dreyfus, who is forced to think and see and read all over again in a new way.

75 Bourget, Outre-Mer, I, 129. This passage can be translated as: "They see things but not the idea... of things. The mind fools itself. The mind knows nothing-there can never be a thinking machine."

76 Stervn S. Schwarzchild, "The Legal Foundation of Jewish Aesthetics," The Journal of Aesthetic Education 9:1 (1978) 35. 
lines recollected from the Latin, such as Ovid's Mens interna sus ne siet usque melis (Of fear that my soul be not always occupied with its own flaws), ${ }^{77}$ introduced with a notice that "I could apply these lines of Ovid to myself" or simply set down on the page with no attribution or contextualization, as with Semper veritas (The truth forever). ${ }^{78}$

There are also clusters of citations, from the ancient classics through to Renaissance writers, such as Montaigne and Shakespeare, constituting a small anthology of aphorisms and commonplaces. But then he has an outburst of personal feelings that trails off into silence and then bursts forth suddenly into an ambiguous Latin tag:

I am always on guard in my obstinate soul. The memory of these long and mournful days where I go, my head empty, body exhausted. In the empty future, dreaming of my destiny ...

\section{Fortis imagination generat casum}

\section{[A powerful imagination produces results] $]^{79}$}

This cri du coeur laments the tedious, empty days he lives through, which he can only endure thanks to his obstinate, obdurate determination. The motto, however, suggests a resolution to this impasse through the imagination, a word loaded with both classical and romantic resonance and beginning to gain increasing power in the new depth psychology of the 1890s. It will be not just an act of the will based on ideological commitment to the cause of justice and truth, but the creative act of imagining - whatever Dreyfus and his age will come to make this word mean, as they go beyond the classical sense of a faculty of the mind to store images, to generate vivid and persuasive pictures in the mind that can reshape those memories, and then the legal or political decisions taken because they overpower other people's recollections and modes of perception.

By adding the dimension of scientific investigations into public 
myths, private dreams, and culturally constructed paradigms of seeing (e.g., phantasmagoria, kaleidoscopes, photography, and x-rays), Dreyfus approaches the more dynamic, generative notions of midrashic visualization. The imagination, in brief, becomes more powerful and productive than the poets or novelists-whether Baudelaire, Mallarmé, or Flaubert-claim because it becomes a faculty through which the mind speculates on historical forces hidden within positive (determinable, measurable) facts and creates previously unperceived insights into itself as a complex, evolving organ of consciousness. ${ }^{80}$

In one rare instance, Dreyfus puts down a line that comes from what the modern editors vaguely designate as the Vulgate: Mori lucrum. ${ }^{81}$ This is seemingly a second unit in the longer passage from the New Testament: Vivere Christus est, et mori lucrum.

It is my eager expectation and hope that I shall not be at all ashamed, but with full courage now as always Christ will be honoured in my body, whether by life or death.

-Phil. I:20

However, while it might perhaps function within this Christian zone of meanings that Dreyfus is thinking of at this time, more likely, from the context and the whole drift of the intellectual content of the prison cahiers, he would be casting such a statement into an ironic or skeptical light, making "To die is to gain" a paradoxical aphorism, reading lucrum less as financial gains or profit than the honor or merit suggested by the New Testament translators, and resonant with anti-Semitic slanders against the miserly and shylockean meanness of money lenders. He thus twists the bigoted connotations around into something like "Through my death I will gain victory over your cruelty and superstitions."

80 Bourget is here talking about the novelist Gustave Flaubert: "Chacun de nous aperçoit non pas l'univers, mais son univers; non pas la réalité, mais, de cette réalité, ce que son tempérament lui permet de s'approprier. Nous ne racontons que note songe de la vie humaine, et, en un certain sens, tout ouvrage d'imagination est une autobiographie, sinon strictement matérielle, du moins intimement exacte et profondément significative des arrière-fonds de notre nature" (Each us perceives not the universe but his own universe, not reality but this reality only what his temperment allows him to appropriate. We only recount our dream of human life, and, in a certain sense, the whole work of the human imagination is an autobiography, if not strictly material, at least intimately exact and proudly significant of the background of our nature) Essais de psychologie contemporaine, 115.

81 Cahiers 1, Folio 34, Cahiers, 59. 
This difficult aphorism is followed by the first of a series of little essays on Nature that appear many times in this and the subsequent prison notebooks. ${ }^{82}$ These meditations take into themselves themes that include the nature of intelligence and reason, the nature of childlike apprehension of the world and scientific investigations, the nature of observing the landscape with the eyes of a poet or an agronomist, and then the powers of the mind through those various eyes to rest passively and muse on the impressions of what is or recollected as what was seen or then to act to change the physical world and thereby also to effect changes in the inner world of thought and feelings. At the close of this first essay on nature, Dreyfus writes:

The law of nature is love. The moral grandeur of the human heart measures itself by this need for, by its capacity to love, the power of a man's mind, in some order which the spirit (or kind) examines in pure science, philosophy, literature, etc., resides in the power to love that in which it is occupies. The law of nature is thus love.

The periodic sentence rolls on through a series of sorites, interlinked and incrementally repeated, enclosed by the same dictum that the law of nature is love. This makes for an attempt to synthesize and reconcile competing attitudes towards the natural world prevalent in the late nineteenth century. But the dictum and the synthesis are too facile, and later versions of the essay begin to explore other ways of approaching the problems inherent in the conjunction of ideologies. For though Dreyfus always tried to be the great peacemaker and resolver of contradictions, he knows that merely wishing for irreconcilable forces to disappear in a lukewarm bowl of chicken soup is not enough; the rabbinical tradition of continuous question, challenge, and dialogue draws him out of these classical and Christian dreams of unrealistic harmony.

In the second essay of the series that follows immediately ${ }^{83}$ he writes instead that the law of nature is love.

Moral guardian of the human heart, it measures itself 
by the need, by the capacity to love, in whatever order of ides this love exercises itself. The law of nature is love.

Stripped to a less complex structure and focused on nature rather than on the contemplating mind, this essay allows Dreyfus to save himself from some of the enthusiastic excesses of the previous piece, but still comes out with an unsatisfactory poetic statement. It is just too facile to equate love and nature as though this were a popular music hall song. He will have to wrestle with this cantankerous problem many times before he reaches a less superficial resolution.

If love stands for the moral guardian of the human heart, then what morality is has to be pulled apart and examined carefully, no more to be assumed a given than nature or love. Dreyfus finds it dangerous to think in these allegorical personifications, although at the same time he finds it all too easy to slide into such essentialist categories of thought when he is suffering from all the woes of his exile and incarceration.

Then in another surprise statement, when he starts a brief critical review of Henrick Ibsen's John Gabriel Borkman, ${ }^{84}$ a play only published in 1896 and thus contemporaneous with his own ordeal, Dreyfus announces that he has just reread the play, "the last work" of this author, and

I can hardly understand the moral worth of this work and it seems to be a weakness in this great man.

What is there in this play?

After a cursory outline of the plot and a sketch of the main characters, Dreyfus asks, "What does the author want to tell us?"

There is only the great foolishness of Erhart who speaks the sentence: "One must live." But what does he mean by "live"? Is it to have fun with Mrs. Wilton? I can't understand?

In one sense, it seems very strange that Dreyfus cannot understand

84 Cahier 1, Folio 38, Verso, Cahiers, 61. The English translation (with no translator named) may be found in Eleven Plays of Henrik Ibsen, intro. H. L. Mencken (New York: Random House. The Modern Library, n.d.), originally from the Everyman Edition. 
this tragedy since it is about a man who suffers from his illusions and a crime committed that he should not have let himself fall into and returns home to a self-inflicted isolation, an exile from the world and the consequences of his incarceration, the two imprisonments both, as it were, the result of what the essayist calls here "the great foolishness" and a little earlier "his great dream." In another sense, everything about the play is based on matters that go against Dreyfus's high ideals and his Jewish perspective on life, both in the confusion of financial and sexual ambitions and in the morbid, relentless self-blinding that overwhelms the protagonist who gives his name to the drama.

Moreover, Dreyfus has gone back to Ibsen because he expects to find a different kind of modern tragedy, a different kind of morality, and the play disappoints on both scores. On the one hand, literature should be moral and possess a social theme, showing how misunderstandings and personal weaknesses lead to crimes and thus to a profound sense of guilt; on the other, Dreyfus wants great authors to probe into the complexities of human character and to reveal the contradictions and paradoxes in well-intentioned people who are driven beyond the limits of their capacity to deal with pain and humiliations through no real fault of their own. Borkman's ideal of creating a financial empire seems paltry to Dreyfus, just as his relationship to the two women he has loved-one truly and deeply but sacrificed to his ambitions and the other less intensely and foolishly, only for wealth and social positionstrike Dreyfus as stupid and obnoxious. Although his own great dream of rehabilitating his honor might seem a foolishness to a more practical or hard-headed realist, for Dreyfus it is precisely the thing that gives both meaning and substance to his life, his family's future, and his relationship to the historical state to which he has pledged his loyalty. Thus, of Ibsen's problematic play, he writes:

I can see no moral thesis. I only see the baseness of mankind in all its depravity, which Ibsen demonstrated in his previous work. But I don't see it here, that which he did in those earlier works: no effort at all for these beings to disengage their senses from their impure complications, the noble effort of humanity to do good.

Because he himself is suffering a terrible injustice and finds the out- 
side world-outside of Lucie and his children, her family and his own, so far as he knows - depraved and both cold and indifferent to his plight and collusive in his torments, now Ibsen is hollow, superficial, and flaccid. True, he was neither a professional drama critic nor a trained philosopher or psychologist, but we cannot deny that Dreyfus had the potential to become a great thinker in the coming century had he not been crushed by his experiences.

Hard on the heels of this little essay, Dreyfus cites two little Latin tags, one of which we already dealt with:

\section{De natura reurum and above all Mori lucrum. ${ }^{85}$}

This linking of the classical to the biblical suggests a new fermenting of ideas in his mind, and one is driven to cite, as Dreyfus does not, these lines from Lucretius, always echoing through his notebooks. ${ }^{86}$

In terms of number of references, Alfred de Vigny seems to be Dreyfus's favourite poet, and one can see why in the first little essay of cahier $2,{ }^{87}$ where he says of him, "The basis of de Vigny is solitude and bitter distress that accompany the sentiment of solitude." These are the leading qualities of Dreyfus's own conditions on the Ile du Diable. The assessment of the poet thus continues:

\section{He has no other resource than flight into dreams like Chateaubriand and lacks in imagination and egotism. He is alone and feels indifferent or hostile to humanity,}

Cahier 1, Folio 41, Verso, Cahiers, 61.

Lucretius, "Fear of Death," On the Nature of Things: "True, men often declare that disease and a life of disgrace are more to be feared than the pit of death. And they may say that they know the soul is made of blood-or else of wind, if by chance their whim so wills it-and therefore that they have no need at all of our philosophy. Yet, you may be sure that this is nothing but idle boasting to win praise, and not their true belief. These same men, exiled from their country and banished far from the sight of their countrymen, stained with some foul crime, beset with disease heralding approaching death, keep going all the same. To whatever situation they come in their misery, in spite all their talk, they sacrifice to the dead, slaughter black cattle, and lay out offerings to the gods of the dead. In their bitter plight, they far more keenly turn their hearts to religion.

"That is why it is more fitting to judge the quality of a man when he is in doubt and danger, and to observe his manner in adversity; for then at last an honest cry is wrung from the bottom of his heart: the mask is torn off, and the truth stands exposed." It will be evident in many of the essays on nature, the mind, and moral philosophy that Dreyfus has read deeply in Lucretius, although he would not agree with all the aspects of such an atomist and epicurean, an epikoros.

Cahiers 2, Folio 2, Cahiers, 64. 
impressive and beautiful nature, those empty skies, and God, if he exists, is dead to the cries of the miserable.

\section{Le juste opposera le dédain à l'absence}

Il ne répondra plus que par un froid silence

Au silence eternel de la divinité. ${ }^{88}$

Whatever merits or demerits there may be in the prisoner's literary criticism, clearly he finds himself able to express his otherwise inarticulate pains and humiliations through this description of de Vigny's character and the citation of these chosen verses.

The next important insight into his character appears in a set of comments given without title ${ }^{89}$ on the power and psychological discourses of literature and history. The first sentence, however, is almost unreadable: "It is curious [two words illegible] in reading writers however famous and of an unprecedented [inoüie] intellectual power [two words illegible] in many of them, the psychological sense is weak, even absolutely missing." This is to be a leitmotif of his own criticism, the necessity of evaluating authors by a combination of their rhetorical strengths, their poetic insights, and their moral (i.e., their psychological) acuity, for these are characteristics he hopes to find in himself and which he looks to create in his own writings, whether in the letters to Lucie, as we have already noted, or here, through a more oblique suite of modalities, in the prison workbooks. Of these modern novelists, he says,

They speak very learnedly in order to use all the language of Rabelais on this or that case of morbidity, on such and such a social situation, accusing them of vices and faults, with a clarity that is often remarkable, without the ability to sense how everything is dependent on man, on his soul-in a word, on his psychology.

The missing words in the opening sentence might help focus on the authors or the type of literary and philosophical movements in the late

"The just man will oppose the disdain of absence/he will no longer reply except with an icy silence/ in the eternal silence of divinity" (my translation).

89 Cahier 2, Folio 7, Verso, Cahiers, 65. 
nineteenth century he is reading and subjecting to this sensitive critique. The discourses of these writers are grounded in a low and mixed language, categorized here as Rabelaisian, but without satire or wit. This new species of literature has turned its focus on to the morbid themes and images of lowlife, crime, depravity, and madness, features of a hostile and confused world that Dreyfus himself keeps fighting against and which he dreams great works of the human mind can help fortify him against and understand. But the poets, the novelists, and the psychologists of his own day disappoint Dreyfus because they wallow in the worst qualities of the human condition.

Such a fact would appear peremptory in a certain class of ideas, when one only considers that the idea will be formally denied when one studies man and the determinant causes of this idea.

Why should such an idea of morbidity seem péremptoire to him? The destructive and limited factor must lie in the narrow focus of authors who only seek out the worst qualities in man to write about and who develop methods of research that narrow down this moral field. In his own experience, Dreyfus has a daily struggle to keep a wider perspective open, and hence he searches for texts that can both guide him through the present tortures and soften their blows until the nightmare of his life comes to a favourable resolution. Above all, he asserts as much to himself as to the authors he is arguing with, it is necessary that one not become obsessed by these idées fixes but seek a higher moral ground of objectivity and dispassionate observation.

Otherwise there are few men so detached from their own ideas as not to be astonished when they no longer serve those to whom they are dear. In all discussions of ideas, each one brings this unconscious false consciousness which is the fact of mankind. And it is this more than anything which must be avoided if one wished to bring to a study, of whatever order it might be, plain impartiality.

The fixation on man's disgusting nature, like all other obsessions, 
must be overcome by a more objective, scientific approach, and yet, as we have already seen hinted in earlier essays and as will become more evident in those that are to come, Dreyfus also looks for poetic insights and imaginative speculations. ${ }^{90}$ Before that, however, he must read his chosen models carefully and keep questioning and challenging them, in accordance with his rabbinical propensities, whether or not he himself is conscious of the paradigm he works within:

No one ever felt this more than Fustel de Coulanges when he said in [one of] his books that before one undertakes any subject in history, it is necessary to disengage from all private interests, from all one's foundations, from all one's own ideas, to study this history in its own milieu where it was elaborated-in a word, in the human context. And that which is true for history is true for everything. And this is one of Fustel de Coulange's highest qualities, this higher impartiality that he brings to his historical studies.

To be sure, such an absolute objectivity is not only impossible to achieve-no one divorces himself from who he or she is and how that character was created by nature and nurture-but even as an ideal goal, it is questionable, as Dreyfus himself comes to remark. In the short run, had such an objectivity and dispassionate approach to evidence been operative in the military courts of Paris, the captain would not be sitting in a lonely prison cell penning these words. The mysteries of what prejudices and distortions of reason were manipulated against him remain to be solved, and the easy casting of blame onto human perversity must be resisted or madness ensues.

As though it is logically appropriate after this praise of Fustel de Coulanges and his ideal of objectivity, Dreyfus takes up a critique of Cesare Lombroso's writings on the relationship between the criminal mind,

90 Cf. Anatole France: "Beauty depends upon ourselves; it is the sensible form of all that we love. It is a mistake to contrast the realist novelists with the idealists. People oppose the real to the ideal as if the ideal were not the only form of the real which we can grasp. The truth is, the realists want to render life odious, while the idealists seek to beautify it" in "George Sand and Idealism in Art," a review of E. Caro's George Sand, On Life \& Letters, I, 303. 
insanity, and genius. ${ }^{91}$ The Italian Jew's work would seem to fit the category of those authors obsessed by the morbid and unable to achieve a detached position from which to measure these qualities, either in his scientific method or in his style of composition. For Dreyfus to find the solution to such theoretical problems, he must wrestle with the authors who most attract him and yet who expose the very faults he sees within himself, for we discover facts about his own character through the choices he makes in what to write about, the places he enters to make his critical comments, and the attitudes he refines as he moves along through the whole of the remaining fourteen prison cahiers.

\section{Lombroso's Theory of the Man of Genius}

The celebrated Mr. Lombroso spent his life in searching to find out cruel truths and those which always charmed. He asked himself, whatever the facts might be-and they came often and, at the same time, they always gave him a formal denial-well, under which latitudes, in what conditions of the ambient milieu are alcoholics, criminals, idiots, deaf-mutes born? In his latest book, he discovered that some great men, belonging to a family of epileptics, have near cousins whose genius is a sort of degenerative psychosis!

Here is an author whose scientific penchant and personal obsession take him again and again to investigate the most degenerate members of the human race. Wherever he looks, he finds these morbid types, and then, of course, he only looks where he will find them. Even when he looks where others have found men of genius, heroes, and supermen, Lombroso finds the defectives and the deviants. In fact, because he looks in this way, the Italian scientist can now claim that degenerates and geniuses are cousins germane. ${ }^{92}$

91 Cahier 2, Folio 8, Cahiers, 65.

92 Cp. Shel Kimen, “The Power of Genius" Concepts of Culture (Spring 2003) online at http://www. klever.org/wrdz/world/genius (seen 1 September 2007). From its classical sense of "guiding spirit" of a person or place, the word came by the 1700 s to designate the importance or influence of a person in society and eventually to mark the inner spirit of creativity or understanding; from thence, it took over the old sense of "virtuouso" as an outstanding performer to become an artist out of the ordinary and above all normal rules of conduct and morality. For Dreyfus, genius is still 
What fascinates Dreyfus here is less the discovery itself than the way of finding it, and the way Lombroso claims to have resisted and denied what he was seeing before his very eyes. Like a good, objective scientist, however, the Italian doctor had to accept his own findings, first resigning himself to the facts and then finally proclaiming the consequences of these facts. "But the facts appeared so manifest to Mr. Lombroso," Dreyfus writes, with his own wit shining through, "that he had to accept them as proof, he tells us with a childish naïveté." The problem, Dreyfus adds, is that

Mr. Lombroso had forgotten that genius is nothing without that which gave it value and which, alone, puts into relief the highest moral values. Worker in thought or worker by hand, all those who have produced great works have a high moral conscience of their duty and of the goal they are pursuing.

What is at stake here in Dreyfus's evaluation of this morbid theory of the close alliance between genius and idiocy is his own sanity and his own need to fight against everything in his circumstances that has been set up to break him, to drive him mad, to make him do as Job was urged by his so-called comforters to do, and accept appearances for reality, rhetoric for evidence, and guilt for innocence. For a man to stand up to adversity, he may have to appear mad to those who want to see him degenerate into their bigoted caricature of what a traitor or a Jew looks like. A high moral conscience, resisting for all it is worth the inner and outer demons of his existence, may finally look like anything at all, but it retains its honour to the very end. A proper scientist should not be taken in by illusions shaped by his own prejudices.

When Dreyfus reads Lombroso's new book, he is, first of all, repelled by the conclusions reached. However, he is not convinced by the facts presented and not sure they are facts at all.

Mais moi qui suis d'humeur difficile et rétive en ces sortes de matières, j'estime que M. Lombroso se contente de peu. 
"But to me," the prisoner writes, "with a difficult and stubborn humor in these sorts of things, I reckon that Mr. Lombroso contents himself with too little." It is important to catch here especially, as from the opening sentences of this little essay, Dreyfus's wit at work, his defensive Jewish humour in his treatment of a fellow Jew-though he never acknowledges that relationship between them. In his darkest hours on Devil's Island, tortured, deprived of all human contact, and without tactile support for his hypersensitive nerves, the captain maintains his dignity through his writing, and his style is not plodding or repetitive so much as it is exploratory, self-analytical, and probing. Here is a respected man of science, a fellow Jew, telling him that great men are virtually the same as idiots on the most basic level of their moral characters and personalities. Dreyfus must reject that. But he himself has to give reasons and not just shout out his defiance in a cry of pain.

He does so in a long paragraph ${ }^{93}$ we must cite and analyze because it is so filled with the ideas we have found important for overturning the previous judgements of Dreyfus's character and personality, as much among those who admire him and his stand as among those who despise him and wish him the worst, as well as those who believe they are merely objective reporters of the facts. But facts in themselves do not constitute truth:

The alienist-physician, who has made the greatest reputation more by his paradoxes than by his books, is a laborious compiler of anecdotes and he gives them to us as unassailable proofs.

Such proofs prove to be mere anecdotes, some curious, some suspect, and this leads Dreyfus to an even sharper criticism, not only of Lombroso but of many others who are mesmerized by their own voices and the illusion of reason where there is only delusion, for the captain is no passive recipient of other people's opinions and he reads carefully and critically.

He affirms that Hegel, in an access of megalomania, had begun one of his lectures with these words: "I may say with Christ that not only do I teach the truth, but I am 
myself the Truth." Whoever knows a little about Hegel will doubt this little story strongly. If Poisson said that it does a man good to know mathematics, would one conclude that Poisson was deranged? Why, one day Ampère, in the heat of a mathematical discussion-and this anecdote is true-took hold of the bonnet of a vehicle and used it for a blackboard so as to re-do his demonstrations, and must we therefore conclude that Ampère was crazy!! . . . All that is naïve and puerile.

These anecdotes may prove that some great men can be occasionally eccentric and even touched in a more acute way, but it doesn't mean that genius itself is kin to insanity or degeneration, nor does it mean that readers should accept every personal report on faith.

I do not wish to follow with the citation of a great number of anecdotes which swarm through Lombroso's work to affirm his theory. I have shown their value sufficiently.

Thus, it is not the theory or the extrapolation of facts that is really at fault but the method of affirming or asserting one's own personal biases without taking into account either the provenance of the anecdotes or the circumstances of the acts or words reported, as well as the tendency to confuse anecdotes with statistics. Hoping that Lombroso or those readers sympathetic to him will not think Dreyfus has an axe to grind (or a whip to lash), the only conclusion he can reach is "The author of these books is himself alienated," a statement perhaps teasingly reflexive, as Dreyfus fears he will be found insane.

Next comes an attempt by Dreyfus to give an English translation of Hume's The Miser, which he must have had in a French version..$^{94} \mathrm{~A}$ kind of Meneppian satire, the exemplary tale describes a miser who refuses to pay the fee to Charon to ferry him into the Underworld, for which Minos decides as a just punishment to send him back to the upper world "to see what use his heirs are making of his riches." Not satisfied with his grammatical mistakes, Dreyfus attempts the translation again and then leaves it unfinished. 
More significant than this momentary view into Dreyfus's intellectual efforts is his essay on another two of his favourite historians, Jules Michelet and Augustin Thierry, and his discussion of the best way for a writer to make use of evidence. ${ }^{95}$ It is Michelet he admires most as a sensitive model for his own writings, but Thierry who is recalled nostalgically as a school text, despite all his faults and failings as a Romantic. What is so special about Michelet is that "he had the patience and the labor of an historian and the pen of an artist." Going much further than Thierry, who was able to assemble vast numbers of facts from his archival documents, Michelet

had recourse to the chroniclers, he interrogated the works of literature and art; a piece of some proceedings, a book of devotions, a monument, a form of architecture often more than the falsified testimonies of historiography.

History therefore is not merely facts and figures, royal decrees and laws, or any other official version of events and persons. Michelet closely studies all works of human genius, including art, spirituality, and political aspiration, not what great men and their lackeys wanted to be known, but what an age really felt that it was experiencing, an age made up of people at all levels and in all walks of life, public and private.

Michelet in all his history is [of the] people and a poet. He had vibrant soul which loved everywhere, sensed everything everywhere, and put his life everywhere. The expression [in his writing] is intense and solid, and he fixes the character of the epoch and draws out of it its beauty. Michelet protests against the Romantics, [but] in reality his history is a masterpiece of Romantic art.

There are inconveniences to this method, Dreyfus knows; he has already commented on the futility of attempting to be objective or to assume that one is implicitly and intuitively in touch with the essence of what one studies and thus does not need to give proofs or demonstrate as valid a technique of interpretation. Although a Romantic in his 
enthusiasms, nevertheless, to Dreyfus, his approach to history breaks the boundaries of formal documentation and opens the research to the study of aesthetics and psychology, along with religious experiences; history belongs to all the people, not just the elite. In Jewish tradition, especially considering the Sephardic sympathies and sense of toleration for the defeated and the downtrodden, history belongs to those who have been beaten down, sent into exile, and made to wander in poverty and despair. ${ }^{96}$

A discussion and a paraphrase of Montaigne comes next, with Dreyfus translating the original Renaissance text into a form of modern French and paring down the text and sometimes recasting what remains to compensate for the missing passages. Like Shakespeare, to whom Dreyfus returns often and leans on as a major intellectual and moral support, and Montaigne, both of whom belong to the tradition of Crypto-Jewish literature, ${ }^{97}$ Dreyfus implies more than he knows he is writing. It is not that Dreyfus does not know he is Jewish or thinks he can hide his religious identity, nor is it a question of whether on certain occasions he would keep some of the traditions at home with Lucie, but that he does not know in a deep way the rabbinical ways of thinking and feeling. More importantly, for strategic reasons, both before and after

96 A rather distorted and toxic version of this view was written by that champion anti-anti-Semite of all time, as his biographer Curtis Cate, put it once, Friedrich Nietzsche, in Beyond Good and Evil: "All that has been done on earth against 'the nobles,' the 'mighty', 'overlords'. . is as nothing compared to what the Jews did against them: the Jews, that priestly people who were only able to obtain satisfaction against their enemies and conquerors through a radical revaluation of the latter's values, that is, by an act of the most spiritual revenge . . . . It was the Jews who...dared to invert the aristocratic value-equation . . . saying 'the wretched alone are the good ones, the poor, the helpless, the lowly ... . You who are powerful and noble are to all eternity the evil ones . . ." cited in Barry Rubin, "The Strangest Antisemite of them All: The Bizarre Case of Friedrich Nietzsche," Gloria Center: Global Research in International Affairs (12 December 2010) at http:// www.gloria-center.org/gloria/2010/1w2/astrangest-antisemite-of-them-all-friedrich-nietzsche (seen 13 December 2010). What Nietzsche was saying was that by inventing Christianity, the Jews committed an unintentional error of cosmic importance. In themselves, Rubin says of Nietzsche views, Jews are a strong and proud people, to be admired and not despised, but the Nazis rendered those philosophical words absurd, putting the blame for all of Europe's woes on the Children of Israel. Thus, the danger of using a rhetoric of exaggeration and irony where feckless, ignorant ideologues can transform them into apologies for genocide.

97 See Norman Simms and Charles Meyers, eds., Troubled Souls: Conversos, Crypto-Jews and Other Confused Jewish Intellectuals from the Fourteenth through the Eighteenth Centuries (Hamilton: Outrigger, 2001). Though Shakespeare's background is a bit speculative still, and the connections are probably through the so-called Dark Lady who was his mistress, an Italian conversa he met through musical performers in London, there is no doubt that Montaigne is the son of a conversa mother-and his scepticism and curiosity are typically converse themes. 
his arrest he feels the need to keep any overt signs or statements of his Judaism under wraps. At work in the army headquarters, he was known to be unsocial and to avoid personal conversations with his fellow officers whom he justifiably mistrusted. After the accusation, arrest, and court-martial, he knew more than ever that censors would be looking for any excuse to increase the harshness of his treatment in prison, and the mere mention of Jewish ideas, images, or acts would sound alarm bells. ${ }^{98}$

The essay by Montaigne he has selected to talk about comes from the Essais, Book III, chapter 5, "Upon some Verses of Virgil." ${ }^{\text {"T9 }}$ The essay Dreyfus writes is introduced by two general statements, one on Montaigne's book in general, and one on this particular meditation on the relationship between classical style, epitomized in Virgil, in relation to French style in the Renaissance. When Dreyfus describes Montaigne's whole book of essays as "easy and simple" in style but "with no unity, no composition," he could be speaking of his own cahiers. When he moves on to the particular essay "On the Verses of Virgil," however, he describes it as engaging "in some unknown way," with its topic, presenting "a citation from Lucretius ... right in the middle of the most scabrous reflections that Montaigne parades before us." Because Dreyfus's own bourgeois sensibilities are offended by the frankness of the language Montaigne uses-and which he elsewhere labels Rabelaisian, that is, earthy and concerned with bodily functions- "I cannot resist

98 According to Max Nordau at the First Zionist Congress, "The emancipated Jew is insecure in his relations with his fellow-beings, timid with strangers, suspicious even toward the secret feeling of his friends. His best powers are exhausted in the suppression, or at least in the difficult concealment of his own real character. For he fears that this character might be recognized as Jewish, and he has never the satisfaction of knowing himself as he is in all his thought and sentiments. He becomes an inner cripple, and eternally unreal, and thereby always ridiculous and hateful to all higher feeling men, as in everything that is unreal. All the better Jews in Western Europe groan under this, or seek for alleviation. They no longer possess the belief which gives the patience necessary to bear sufferings, because it sees in them the will of a punishing but not a living God" (MiddleEastWeb). Although Dreyfus would never have considered himself one of those New Marranos, as Nordau calls them, who try to flee Judaism, while being unable to escape from themselves, he does seem to work out a temporary modus vivendi through his writings, first in the letters to Lucie, where they jointly create a new kind of metaphysical love and a new kind of space for their domestic hopes, and then in the prison cahiers, where he forges a temporary pseudoTalmud in which he can speak in a traditional rabbinic way, even though the specific subjects are alien to midrash.

99 This little essay on Montaigne is not all that little insofar as it contains Dreyfus's lengthy paraphrase, and runs over several folios of the workbook. Cahier 2, Folio 13, 13 Verso, and 14, Cahiers, 68-69. 
the temptation of reproducing this exquisite chapter, except perhaps in passing over several of the facetious remarks which Montaigne permitted himself to make." To our own twenty-first century sensibilities, it seems most odd that a man who is living in squalor and under atrocious conditions, who has been subject to physical and moral indignities day and night for four years already, should find himself unable to set down in his own words equivalents to Montaigne's sixteenth-century vocabulary in matters of this kind. Yet this is what Dreyfus says and what he actually does in producing his abbreviated version of the essay.

What attracts Dreyfus to this exquisite essay on style despite its scabrous remarks are Montaigne's reflections on training oneself to be healthy and sane from childhood onwards in order to prepare oneself, as Virgil did, for the moral life necessary to becoming a great poet. By making oneself strong and gaining self-control over one's bodily needs, Montaigne reflects that it is possible to achieve the strength of character that can resist all the temptations of maturity and prepares oneself to confront the coming of old age when the decline of those physical abilities mocks the desires to still perform them. At such a time, arrived at an age when one feels oneself "[a]ll dried up and weighed down" by the burdens of life, poetry provides both a comfort and a channel through which the remaining passions can run their course. "Venus," writes Montaigne in Dreyfus's paraphrase, "is not so beautiful all naked, nor so alive and breathless, as she is in the verses of Virgil."

Through citations from Virgil and Tasso, the Renaissance essayist expresses his longings and explains his appreciation for style, arguing that art becomes consolation and a mode of creation when physical relief has become impossible and the days of reproduction are over. Can it be that here, squeamish as he appears and yet fascinated both by the Old French language and Montaigne's citations from sensuous poetry, Dreyfus is indulging in erotic fantasies, dreaming of the most intimate of moments with his wife, Lucie, which he could not even bring himself to think of, let alone inscribe, in his letters home? It would certainly be remarkable if, through all the years of separation, and yet under constant scrutiny by guards-including through the nights when he was sometimes shackled to his bed by iron chains-a still young, though hardly at this point vigorous, man, did not seek some physical outlet for his frustrated desires. Dreyfus distances himself from these unperformable deeds and unthinkable thoughts, first through reading Montaigne's 
essay and choosing this particular one for such an extended discussion, and then modernizing the language into his own and therefore controllable terms, editing out the most intense locutions, thus allowing Montaigne, Virgil, and Tasso to express what he cannot admit to imagining for himself.

At the point at which Montaigne begins to follow Virgil's descriptions, mythologically and pastorally, of the affairs of Venus and Mars, he comes to a line from the Georgics, III, 137f:

\section{Quo rapiet steins Venrem interiusque recondut . . ${ }^{100}$}

At this point, Dreyfus stops and leaves a large gap in the text of Montaigne before he picks up his paraphrase again, but, even then finds himself entwined in a style of verbalized sensuousness he must have found as fascinating as troublesome. Yet it is Montaigne himself and supposedly not Dreyfus who says,

I am vexed [bothered, frustrated] at the same small points and verbal allusions that have been born since. To these good people, one must not encounter [embrace, be intimate with] them with sharp and subtle words. Their language is firm and right and great with [pregnant with] a natural vigor and contrast-they are all epigramme, not by tail alone, but by head, stomach and feet. . . .

The sensuousness of the sentences slip by, barely subject to Dreyfus's sense of propriety and his strenuous efforts to censor his own improper thoughts, until Montaigne cites, "It is sinewy and solid eloquence which does not so much please as it fills and ravishes." Montaigne keeps going, citing Quintillion, Gallus, and other classical and later authors; Dreyfus trails off into longer or shorter ellipses until he concludes, in Montaigne's words:

It also happens in my writing, as in a wild country, where no one either aids me or relieves me, when I ordinarily hear men who understand neither Latin nor French. I

100 "It is thus that the [thirsty female] seizes Venus and becomes most deeply impregnated." 
would have done my works elsewhere, but it would have been less my own, and its principal end and perfection is to be me.

With almost no adjustments necessary, these also could be Dreyfus's deepest sentiments. For those historians who still say we know almost nothing and cannot know anything about the inner man of Dreyfus, surely it is time to read and to listen to what remains of the evidence in these cahiers, as in the letters. His wild country was a deserted and insalubrious prison island. Although there were guards constantly observing and manhandling him, he was locked into a silence and solitude beyond the limits of almost any other prisoner in modern history. ${ }^{101}$ Paradoxically, however, it is unlikely that Dreyfus would have ever permitted himself the time and energy needed to compose the essays he did had he not been held in an extended period of torment and humiliation. We search-so far in vain-for evidence in any later documents created after his return to France of the articulation of so many literary, philosophical, psychological, and religious ideas.

What he writes about next after this discussion of Virgil's style, by which is meant nothing less than the capacity of a writer to subsume his own sensual urges into beautiful poetry, is one of the strangest books about prison life in the nineteenth century, Xavier de Maîstre's Voyage Around My Room. ${ }^{102}$ As Sainte-Beuve points out in his introduction to the 1862 edition of de Maistre's Ouevres Completes, the younger brother to the more famous novelist Joseph composed this lighthearted and sentimental idyll inadvertently as a joi d'esprit, adopting the tones and often the phraseology of Lawrence Sterne's Sentimental Journey, itself more popular in France than the more impressive and profound Life and Opinions of Tristram Shandy.

In forty-three chapters, de Maîstre records his imaginary excursions around the room where he is kept under house arrest in Turin at the time of the Napoleonic Wars, each short chapter consisting of a musing on some object, portrait, or moment of memory in his confinement.

101 Except perhaps those exemplars in allegorical fictions, such as Robinson Crusoe, or in romantic novels, The Man in the Iron Mask, The Prisoner of Zenda, and so forth.

102 Cahier 2, Folio 16, Cahiers, 70. The Oeuvres Completes du Comte Xavier de Maistre were published with Sainte-Beuve's "Notice sur Xavier de Maîstre" in Paris by Garnier Frères in 1862, including drawings by Staal and engraved by several hands. 
Dreyfus says he is attracted by the "soft, amiable figure of Count Xavier," but although he cites some of the poetic lines from the text, surely it is the very condition of imprisonment that he identifies with, although, of course, the differences between what the nobleman underwent and his own circumstances are striking. De Maîstre had a manservant, lived in a well-appointed apartment in the middle of Turin, whose streets, parks, and crowds he could observe through his windows, and his house arrest lasted barely a month and a half. Dreyfus could only envy the author of this "soft" book and its poetic dreams.

The next little essay returns his attention to more serious matters. This discussion of the Abbé Félicité Robert de Lamennais (1782-1854) reflects on the questions of religion, strength of character, and the relationship of faith to science. The standard view of him is that he "fit un effort pour adapter le catholicisme à une société plus humaine" (made an effort to adapt Catholicism to a more humane society). ${ }^{103}$ His theories have been summed up in this epigraph from the newspaper Avenir ( $\mathrm{Fu}-$ ture): "Dieu et Liberté" (God and Liberty). He also argued in his Essai sur l'indifférence that the greatest danger to the Church comes not from its enemies without but from the indifferent members of its congregation. Dreyfus may have agreed in general to some of the principles here but would not have been interested particularly in theological or pastoral matters within the Roman Catholic Church. Was there, rather, anything particular in Lamennais's character or career ${ }^{104}$ to attract Dreyfus? When the young critic Sainte-Beuve went to visit him in May 1830, he found him "a drab, dusty little man, who looked like a village sacristan." ${ }^{105}$ According to Harold Nicolson, he was also "a melancholy man who took a pessimistic view of the century . . by nature timid and irresolute,"106

103 E. Abry, C. Audic and P. Crouzet, Histoire illustrée de la litérature française (Paris: Henri Didier and Toulouse: Edouard Privat, 1942; originally 1912), 475. This revision of an old school textbook under war-time censorship gives a noncontroversial view of French literary history, the new editor declaring it "un acte de reconnaissance et un acte de foi" (an act of gratitude and of faith), gratitude for being able to present to the reading public an up-to-date version of this book with four new chapters on the major authors from 1900 to 1938 and of faith in the integrity and viability of French civilization after the defeat by Germany. There is, of course, no mention of the Dreyfus Affair, the facts of either Nazi occupation nor of Vichy rule in the southern zone, and the few authors with Jewish background not noted as such.

104 A sort of biography is given in the entry on Lamennais in The Oxford Dictionary of the Christian Church, [ODCC] ed. F. K. Cross (London: Oxford University Press, 1963 [1958]), 781b-782b.

105 Harold Nicolson, Sainte-Beuve (New York and London: Constable, 1957), 45.

106 Abry, Audic, and Crouzet characterize him as already in his childhood displaying "une âme inquiète et indépendante" (an agitated and independent soul) in Histoire illustrée de la litérature française, 475. 
and yet he was "inspired by a fervent conviction that man was too weak to be accorded the right of private judgment." What could possibly have appealed to Dreyfus, who, unlike Sainte-Beuve, was at once "fortified and perplexed" by his encounter with Lamennais? ${ }^{107}$

The life of this Catholic rebel begins with him losing faith at an early age (through the reading of Rousseau, it was said) and then being led back to the fold by his more pious brother, Jean-Marie Robert (1780-1860), then taking orders at the age of twenty-two and eventually becoming a professor of mathematics at the episcopal college of his birthplace, Saint-Malo, in $1804 .{ }^{108}$ When we look at the trajectory of his life, we see that he was a troublemaker from the beginning, asking too many questions and challenging the authority of the church. His first book, Réflexions sur l'état de l'église (1808), was suppressed by Napoleon. Though an apologist for Ultramontaine Catholicism, he appealed to royalists and conservatives, but his repeated calls for religious freedom made him always suspicious to the hierarchy.

In Essai sur l'indfférence en matière de religion (1818-1824), ${ }^{109}$ Lamennais "reproached the upper classes of his time with infidelity, and with giving all their aspirations to temporal matters." ${ }^{110}$ For his liberal Fideist views, ${ }^{111}$ including an appeal in Paroles d'un croyant (1834), ${ }^{112}$ in which he called upon the Holy See to accept democracy, he was denounced as a subversive and castigated by Pope Gregory XVI in $1832^{113}$ and then, as Nicolson puts it, "spent the rest of his life attacking the Vatican,"114 with a tendency in his writings towards a humanitarian socialism and mysticism. "Active in the 1848 revolution, he sat in the Assembly until

107 Nicolson, Sainte-Beuve, 43.

108 ODCC, $781 \mathrm{~b}$.

109 Chambers Biographical Dictionary [CBD] calls this book "a magnificent, if paradoxical denunciation of private judgment and toleration, which was favorably received at Rome," ed. Magnus Magnuson (Edinburgh: Chambers Harrap, 1995; based on the original 1897 edition), 853b.

110 S. Reinach, Orpheus, 407-408.

111 For background on these movements and the personalities involved in early nineteenth-century France, see Salomon Reinach, Orpheus: A History of Religions, trans. Florence Simmonds (New York: Liveright Publishing, 1930; orig. 1924), Chapter XII, "Christianity: From the Encyclopædia to the Condemnation of Modernism," esp. 94-95, 433-434.

112 One bishop called these Words of a Believer an "Apocalypse of the devil" (S. Reinach, Orpheus, 407). CBD describes it as the book "that brought about complete rupture with the church" and resulted in one year's imprisonment (854a).

113 S. Reinach, Orpheus, 407.

114 Nicolson, Sainte-Beuve, 46. 
the coup d'état." 115 According to Frank Paul Bowman, after the coup in December 1851, "He retired to private life ... and, as he had requested, was given a pauper's burial." 116

If it is not possible to see any continuity or a clear development in Lamennais's themes, it might be possible to credit him for working with two sets of ideas that in other thinkers might have been too contradictory to be sustained, but although these inconsistencies infuriated others, even his friends and admirers, they nevertheless marked him as one of the great if quirky philosophers of the first half of the nineteenth century. ${ }^{117}$ On the one hand, Lamennais proposed,

The principle of authority, which he equated with the "raison générale" or "sens commun." He maintained that the individual is dependent on the community for his knowledge of the truth; to isolate oneself is to doubt; and toleration is evil. ${ }^{118}$

Thus, at the same time as he challenged the moral authority of the pope and the church hierarchy, stating that they were not above reproach, he also argued that ordinary men and women were incapable of making decisions of faith on their own and should yield to the spiritual powers of the church as guardian of traditional beliefs. But he also

$$
\begin{aligned}
& \text { equated Catholic Christianity with the religion of all } \\
& \text { mankind, denied the supernatural and proclaimed sub- } \\
& \text { jects freed from loyalty to their temporal sovereigns }
\end{aligned}
$$

115 CBD, 854a.

116 Bowman, Lamennais, Oxford Companion to French Literature online at http://www.answers.com/ topic/lamennais-f-licit-robert de (seen 01 January 2011).

117 CBD calls remarkable his Esquisse d'une philosophie (1840-1846). Of this four-volume treatise, The Catholic Encyclopedia writes: "It comprises a treatise on metaphysics in which God, man, and nature are studied by the light of reason only. Many of the opinions maintained in this book remind one that it was begun when its author was a Catholic, but there are many others which betray his later evolution; he denies in formal terms the fall of man, the Divinity of Christ, eternal punishment, and the supernatural order. The portions of the work devoted to æsthetics are among the finest that Lamennais ever wrote, while the general tone breathes a spirit of serenity and calm" online at http://www.newadvent.org/cathen/08762a (seen 01 January 2011). Frank Paul Bowman in his entry on Lamennais in the Oxford Companion to French Literature calls it "an ambitious synthesis of Romantic aesthetics, German transcendental philosophy, Christianity, and dreams of a new faith yet to come."

118 ODCC, 782a. 
when rulers refused to conform their conduct to Christian ideals. ${ }^{119}$

If these controversies were merely squabbles within the Roman Church, they would have no interest for Dreyfus, but what attracted him was the intellectual struggle itself. Perhaps, then, he would be interested in the ideas discussed, especially Lamennais's drift towards a more tolerant and liberal modernity, albeit with a strict sense of the weakness of ordinary people and the power of the church as an embodiment of traditional truths. Raphael Ledos de Beaufort sums up the key matters after the Revolution of 1830 in this way:

Lamennais was no longer the defender of Catholicism or the champion of the Restoration. Times had changed since the Breton abbé in his "Essai sur l'indifference en matière de religion" endeavoured to restore public faith in the principle of authority, thereby causing quite a sensation, and winning from the enthusiastic gratitude of the supporters of the Church the proud name of "Bossuet Moderne". In 1831, he had already in various articles which he contributed to the newspaper L'Avenir [The Future], placed himself in opposition to the past. In these he had tried his democratic strength, and stood up in the contest as the powerful and gifted advocate of Christian brotherhood and freedom, which, when released from its subjection to princes, should unfold itself under the banner of the Church. ${ }^{120}$

Beaufort also explains why this modern Bossuet was attractive to fiery young men like Franz Liszt in this late Romantic period:

Lamennais's true piety, his democratic principles, his

119 ODCC, 782a.

120 Raphael Ledos de Beaufort, Franz Liszt: The Story of his Life (Boston: Oliver Ditson \& Co., 1887); because this book is reproduced in the Project Gutenberg, it can only be annotated by chapter number: Chapter XIV. (It will be noted that, except for the insertion of my own contemporaries' remarks on the nature of anti-Semitism and attitudes towards Judaism, I prefer to cite texts close in time to Dreyfus. This is part of the midrashic method of challenging and questioning the text.) 
views on life, imbued with love of freedom and humanity, and which led him boldly and violently to break off with the Church and with his glorious past, found an echo in the generous and impulsive soul of the young artist, and ripened the Christian ideal views of art already awakened by the doctrines of the Saint-Simonians, and which were to give foundation to his artistic career and productions.

Sainte-Beuve, who was disappointed by the way Lamennais broke with the Church, wondered whether this once admirable writer had become neither a priest nor a philosopher: "Was he nothing more than a fine but ambulating artist? . . . It is a misfortune to possess a mind that never ripened." 121 Can something similar be said about Dreyfus? He seems attracted to this contentious and melancholy Catholic writer a little over sixty years later, not by his specific ideas or faith, which would not interest him at all, but by what happened to him when the pope attacked him and how he reacted; that example might be attractive-up to a point.

Dreyfus begins his own little essay by saying,

Certain men are interesting by the unity of their doctrine, by the force of their character, the logic of their system, their general intelligence which permits them to embrace in one ensemble everything in a vast system of ideas and to bring in all secondary ideas which circumstances, reflections, facts are caused to stand before their mind to create a synthesis, in a word, a doctrine.

This opening by way of a truism (a sententia) indicates that there are more ways than one to attain greatness as a thinker, whether in religion or in any other field; consistency and constancy are not necessary, which is a comfort to Dreyfus, who finds himself, under the duress of his imprisonment, forced to rethink his ideals and his attitudes, while at the same time asserting over and over again his steadfastness in regard to his loyalty to France, the love he has for Lucie and their families, and 
the honour that he must regain at all costs. In Lamennais, he sees a man who seemed to vacillate, to shift and change his views under the pressures of theological authoritarianism and in the context of revolutionary transformations of French society.

Hence, the second paragraph balances the first statement, offering an alternative way to greatness, that of Lamennais and perhaps of Dreyfus himself.

Others, on the contrary, are interesting by the variation of their thoughts. Above all and, at best, it is on recognizing that they were not the result of powerlessness, but rather the unintended logical development of a living idea, one that changes and transforms itself.

Since thinkers cannot always, from the beginning, know the full context or the hidden forces at work in the circumstances they must work in, a doctrine may develop out of the logic of its own engagement with the world and not merely by the intentions of its author. These divergences come about out of strength instead of weakness, the writerLamennais or Dreyfus-proving in adversity that he can follow where the truth leads him, not where others wish to direct his career.

The next sentence loses itself in a smudged word or two, but shows the importance of that very defiance of external power, whether of the state in all its mysterious machinations or of sadistic individuals who revel in treating a prisoner with contempt:

On the other hand [illegible words] . . Considered from the one or the other point of view, the thought and work of a man becomes, following the very expression of Lamennais, his memoirs serve as a history of human thought. They show in one such man, as happens so often in the history of humanity, a doctrine, the steps or questions of which are all logical, or all at least having their own profound reasons being, touching on the contrary.

After this point Dreyfus reaches a conclusion about the relation of science and religion which does not come down on either side but seeks 
a reconciliation, a harmony, and a balance to make peace in the house (shalom ba'bayit).

\begin{abstract}
All religion is the explanation of things by the supernatural, all science excludes the supernatural in its research, and all scientific philosophy, even the most elementary kind, eliminates the supernatural, at the same time at the point of departure and at its goal.
\end{abstract}

By this he argues that religion and science are different, to be sure, but difference does not make one more correct or apt than the other. Both are intellectual systems of thought. Two out of the three clauses in the sentence come down on the side of science over religion and do not cancel out the first. ${ }^{122}$

In his next essay on Shakespeare's King Lear, ${ }^{123}$ it is likely that Dreyfus is talking at least as much about his condition and feelings as he is about the characters in the tragedy. The essay is not an example of literary criticism in any objective or historical sense but an exercise in confessional inner dialogue, ${ }^{124}$ an exposure and expression of his own secret pains, his repressed grief and sorrow, as well as his rage against the injustices of the world and his doubts about the firmly-held beliefs and ideals he is suffering for. Although he seems to focus on Shakespeare's text, his own syntax trembles and falters. He fumbles for words, he repeats himself awkwardly, and he gets lost in the convolutions of his grammar, so the little essay becomes, as it were, a mirror held up to his own mind, an embodiment of the deepest agony within his own soul.

There are two ostensible points of self-identification in the tragedy: first, he grieves with and for Cordelia, expressing a sense of anguish and outrage he elsewhere attempts vigorously to keep under control, fearing at every moment the bursting forth of sheer madness; second, he sympathizes with the old king, and yet the scene he chooses to concentrate on is one between Lear and Kent. In reading those lines of the play, he goes over the questions of justice, loyalty, and self-sacrifice that are not

122 The little essay on Lamennais ends with a mysterious line: "I have pushed towards F too slowly." At this point, I will not venture a wild guess as to the meaning of this.

123 Cahier 2, Folio 20 and 21, Cahiers, 71-72.

124 "Mahloquet is a way of speaking and of thinking the refusal of synthesis and of system: an antidogmatism that, alone, makes possible the living truth" (Ouaknin, Tsmimtsoum, 110). 
only pertinent to his own situation but form the repeated motifs in his letters to Lucie. It is possible to extrapolate from this essay some of the key phrases and sentences that expose the elusive inner world of Alfred Dreyfus:

The excess of misfortune and the black anguish of the heart makes this piece of drama the most . . grievous that was ever written ... I believe that there is not one which wounds the heart more grievously than that of King Lear; for there is no other which shows more profoundly the unbelievable feebleness of human nature. In order to destroy the happiest of conditions, it takes only one word, one remark-such is human judgement, where prejudices and passions are involved-it is feeble, it staggers. . . . Our sentiments are less certain than those of most honest beasts. . . . they are so trusting, that they do not know how to distinguish true sentiments from [illegible words] and threaten them.... But, alas, how many men at all times and in all countries do we not see ... with their high-flown notions of responsibility ... fooled previously by the over-confidence they have in their own power. . . . The unbelievable blindness of human nature creates the sombre sadness of Shakespeare's drama....

Grief, weakness, and blindness are the key factors in his identification with the tragedy, the main elements in his own tragic life.

After a brief stanza by Hegisippe Moreau, ${ }^{125}$ Dreyfus begins two long essays, one on art $^{126}$ and the other on beauty in Michelet, ${ }^{127}$ to be followed themselves, strikingly for our purposes, by a discussion of photographic equipment. ${ }^{128}$ While we shall have much more to say about

125 Cahier 2, Folio 28, 72. Perhaps in this little poem, Dreyfus finds a dreamy image of his horrible torment when shackled to his bed. "On the cot [grabat], hot in my agony, /For the pity I still find in tears, / For a perfume of glory and of genius/ Is spread on this bed of pains [ce lit de douleurs];/ It is that what comes, widow of hopes/ To sing again, then to pray and die."

126 Cahier 2, Folio 29 and Folio 29, Verso, Cahiers, 73.

127 Cahier 2, Folio 30, Cahiers, 74.

128 Cahier 2, Folio 35, Verso, Cahiers, 75. This essay is preceded by a few brief remarks on Henry IV and an aphorism: "No one is great to his valet de chamber." 
Dreyfus's attitude towards art, aesthetics, and the psychology of seeing in the next book in this series, when we return to a long discussion on his many drawings or doodles in the cahiers, it will be important to run through the key ideas he presents in these three essays. It is sufficient here to notice that the psychological bent to his critical remarks on literature, philosophy, and history is also relevant to the way he considers painters, musicians, and other artists. He knew what Paul Bourget wrote in his Essays on Contemporary Psychology: that there is a theory that considers our "ego" to be "a bundle of phenomena ceaselessly in the act of making and unmaking itself." 129

The essay on art starts with general statements, truisms, which as we will see can belong to the general cultural milieu around Dreyfus but also can be seen to have peculiar aspects that derive from his own mentality and also from a more specific tradition of rabbinical visual midrashing of beauty as both service to God and creating an aesthetic of the law. Not all these aspects of the topic will be contained in this first of many little essays to be found in almost every one of the remaining cahiers, and not each essay will handle the topic clearly or coherently, but the ideas are working through Dreyfus's mind whenever he can find the moments of sanity and calmness to let them:

\section{Of Art}

Art has in its hands all the power of creation, all that the poetry can do, the passion, the grandeur of a human period; all the aspiration, towards the Ideal, all the pantheistic images, all which falls from the sky or all which lifts itself from the earth.

The human labour that produces this category of externalisation of beauty participates in a vaster, divine project of creation. It is a process generated-and generating itself, as one can see from the personifica-

129 Bourget, Essais de psychologie contemporaine, 157: "la théorie psychoogique qui considère notre 'moi'comme un fasiceau de phénomènes sans cesse en train de se faire et de se défaire." This "collection de petits faits" (collection of small facts) constituting the "moi" (ego) accords with both Taine and Flaubert but lacks the dynamics and moral direction that Dreyfus considers as essential to the individual struggling to maintain his personality under the most desperate of circumstances (cf. Bourget, Essais de psychologie contemporaine, 163). 
tion of art in the first clause-by mental and manual labor (avodah), work that is a necessary duty and a voluntary service-and that leads the maker towards the ideal, the perfection, and thus within human experience and history towards the process of perfecting of what is imperfect. The labor of art reflects itself into poetic, passionate, and pantheistic images, merging both what has fallen from the heavens like manna and what is produced on earth and seeks to rise above it, each after its own kind by natural growth. While some of these statements can be set within rabbinical discussions about beauty and truth, the words and phrases here are vague and confused in themselves. Can Dreyfus clarify what he means to say?

Here is what art reflects (reflète), art; here is the chaos in which art kneads or moulds (pétrit) the life of thought, in order to represent all its manifestations.

The juxtaposition of two different metaphors to describe art is at first disconcerting: as a process of reflecting, such as in optics and its modern developments into photography and x-rays, and as either in a baker kneading dough in preparation for baking bread or a potter moulding clay in preparation for placing it in a kiln. ${ }^{130}$ In either of these views, what is without form is given form through human effort, and the world of tohu v'bohu, the original chaos, becomes in an orderly, thoughtful sequence of actions the world of order and harmony.

Art has its doctrines as religions have their rules or laws, not that these doctrines must be immutable-to hear the heart beating, to set thoughts free to flow, to give life an energy to all human aspirations: here is the doctrine of art that must rule over the odious hairshirt (cilice),

130 "At times, the reliance of the artist on specific photographs done by others may border on slavish imitation. This accurate rendition of a photograph was, of course, precisely what was demanded from an engraving artist concerning a photograph into an engraving. This was the only viable way for publishing photographs before the introduction of photo-mechanical printing later in the [nineteenth] century ... However, especially in the case of landscapes, the engravings were often modified slightly; an imaginary reality was introduced to accommodate some pictorial convention that was not necessarily commensurable with the original photograph," Haim Finkelstein, "Lilien and Zionism," Assaph: Studies in Art History: 3 (1998), 208; online at http://www.tau.ac.il/arts/ projects; http://www.melalexenberg.com/paper.php?id=2. 
that is to say, the rule of Aristotle, Longinus's On the Sublime and Boileau's Art poétique. Method (la méthode) is a refuge for the sterile (stériles); for the others, she is a guide, a preparation for the hand of the sublime worker (ouvrier sublime).

The typical nineteenth-century notion that art is itself a religion developed to compensate for the secularisation of society and the breakdown of formal religions. If art is not to be seen as a religion for people who have lost faith in the old myths and truisms, it can at least be taken as a starting point for Dreyfus's critique of classical and enlightenment rationalism. It is not that this new religion has no rules, but that they are not constrictive and deadening: they are the laws of following the impulses of nature and the release of ideas to grow and develop as they will. Method in itself is not wrong: it is a refuge, an excuse or a subterfuge, for the sterile soul, while for the sublime worker, it is a preparation or a training for the exalted tasks ahead. Again we watch Dreyfus trying for a compromise, a harmonization of seemingly incompatible views, and see that this is a man who thinks, perhaps without knowing it, within Jewish patterns of thought-even though, to be sure, those rabbinical themes can be found elsewhere and can be expressed often in a language Judaism shares with (if not bequeathed) to Christianity and the modern secular world coming into being.

In this little essay, for the most part, Dreyfus writes in a language of romantic idealism, using excessive superlatives and absolutes, so that as he writes he must keep adjusting his perspective, modifying his terminology, and not always succeeding in this endeavour, so that he comes back many times to try to write the same thoughts from a slightly different angle. This kind of style-he has no thoughts of publication in mind, nor does he have any partner with whom he can try out his ideas in conversation-is the manifestation of the inner dialogue with himself that he writes to Lucie about in their letters.

Art in its supreme mission must ceaselessly aspire to the infinite, such as to ascend the bleak and rough (âpre) mountain, where the Ideal flourishes. But if art sometimes lacks stamina, if, in certain epochs, it is incapable of reaching the highest summits, for art is the reflection 
of each era's soul; it always follows the truth that emerges from the depths, completely naked and continuously shimmering.

The goal of art, its quest in some romantic mission, is to climb the highest mountain and retrieve the magical flower growing at its peak; this is a fairy tale, in which the young aspirant to marry the king's daughter-here it is art personified in each era as a different youthful candidate-does not have the strength to succeed; nevertheless, in every age, the ideal is always the same, Truth, in all her naked and glorious beauty.

The Ideal and the Truth here are the two supreme characteristics of Art: those that unite the two radiant faces of Beauty, and thus able to produce a masterpiece. Without, however, arriving at this supreme expression of art, each one may be permitted to use his talents according to the nature of his own means, allowing one to be a scholar, the other an original, one a poet sure of his form, the other a pantheist who loves all that is alive, with no concern for higher thoughts or the mystery of creation.

These abstract hypostatised personifications do not necessarily require that each and every artist be perfected in his or her skills, and each may choose his or her own particular way of approaching the idealized goal. Just how the artist goes about the specific duty set by his own mind depends on many factors:

But before the hand executes [the work of art], it must always [be put in] place the thought that inspires it; the eyes and the soul fly in advance of all the others. Thought, this is the genius of all activity in which the order of art, which this thought exercises itself; thought, that is, God, though has no limits at all, like Jupiter's eagle soaring above the world.

While this sounds like a paraphrase of a poem by Keats or Shelley or almost any other Romantic poet, there is also something peculiar, not just in the awkwardness of Dreyfus's syntax as he attempts to soar in his own enthusiasm but also in his hesitations about dwelling too long in these platonic categories, not least the notion that God is merely the name for our own idealized thought (la pensée). Then the allegory continues to unfold: 
Execution, the daughter of Study, is material art, submitting to certain laws, chained to certain modalities. Genius is not the work (oeuvre) of chance, but the work (oeuvre) of thought.

The key word here is œuvre, which may mean a range of things, such as a product, a pew (seat in a church), or a setting (on a ring for a precious stone), or even an action (in a performance or staging of a play or choreographing of a ballet). As for la Génie, it is not so much either the Genii of the Arabian Nights or the brilliance of a unique mind so much as the manifestation of the power of creation, the thing produced, along with the force that creates and its guiding principle. It is something intellectual rather than an irrational burst of external energy. This rational, intellectual, and controlled operation in the process of art is something Dreyfus makes the otherwise hackneyed iteration of the Romantic dream mean.

Then comes an exemplary tale to animate the personifications introduced and identified above.

Timanthes wished to paint a storm, He went to the seashore on a stormy day; he observed but he didn't think. He believed that he knew how to paint a storm. He made a work that had neither soul nor life and broke his brushes. Another day, this same Timanthes entered a school of rhetoric; he heard them reading Homer, he felt his heart beating, his imagination was inflamed, he ran to his studio, he took out his work and painted a tempest which astonished [even] him (l'épouvanta lui-même).

This is a traditional exemplar on the power of art to astound through rational schooling of the senses and the skills of the craft. An ancient Greek painter, Timanthes, learns how to become an artist not when he studies the techniques (technē) of his craft but when he hears how to read-that is, to listen intelligently in a school of rhetoric - the classical verses of Homeric epic. He does not need to paint en pleine aire, as many of the nineteenth-century Impressionists believed, or by copying old masters as the teachers in the École des Beaux-Arts insisted, but by 
doing both, by learning to order his thoughts through the discipline of the schools. He could then return home, take up the plank of wood upon which he was attempting to put down his impressions of the storm he had experienced on the beach, and now create a work of art, a product of the human mind.

On the second folio of this essay on art, ${ }^{131}$ Dreyfus moves back to a discussion of artistic theory, aesthetics, saying,

The search for the beautiful has occupied all philosophers, as it has all artists. They are thus one or the other guided by genius, the ray which lights up the soul as the sun lights up the world.

Unlike the artist proper, who seeks to produce his objet d'art by using the material means available to him in his own time and place, the philosopher searched in theory for the ideal, yet both of them are directed in their search by their own genius, a ray of light from some higher realm. Dreyfus then turns to the debates between the various schools of artists and theoreticians active in his own period of history.

\begin{abstract}
Also, how often do we see this in the battle of the schools - those of the idealists and of the realists. Idealism, as I have said, would speak of Beauty in its two conceptions, the Ideal and the Truth. Take the example of a realist's painting of a domestic interior, man in all his material reality; we can neither scent the perfume of the soul nor see the spirit of the home. The same picture, inspired by a thought will give us the soul do the interior scene, will give us mankind and not a man.
\end{abstract}

Instead of speaking, say, of the Impressionists and the Naturalists, or of the official painters rewarded by the Salons and those new movements forced to set up their own private exhibitions to win public approval and sales, Dreyfus chooses these two more traditional ways of looking at art. For him, the realist painters are those who copy nature, who see as the ideal of art the ancient concept of mimesis, with all the 
mixed feelings that the classical thinkers roused in their discussions: whether the best painter was the one who could so reproduce the appearance of flowers or grapes that flying creatures would be fooled and crash into the walls upon which they were depicted, or even, like the Dutch and Belgian old masters, create realistic paintings of domestic interiors that seem to be virtual photographs of their genre scenes, or whether the ideal to be aimed at was that exemplified in the tale of Timanthes, who had to train himself in the power of rhetoric-learn the art of imitation in terms of enargaeia, vivid illusions of reality based on conventional patterns of thought. The mere illusion of reality, the photographic reproduction, lacks the soul that true art aims for and sometimes achieves. ${ }^{132}$ Otherwise the viewer cannot smell the perfume of the living soul nor feel the spirit of the home. The goal is not the individual and the instant - the impression of the artist's neutralized sensorium, his or her "negative capability," as Keats would have saidbut the universal and the eternal. ${ }^{133}$

Idealism and Truth in its sublime concept of a humanity which progresses, in its Beauty; Realism is the truth of a single point of detail which cannot interpret humanity and which is false because it is only of an instant.

Although somewhat crabbed and awkwardly expressed, this contrast between idealism and realism continues Dreyfus's main argument. Idealism contains as a complement the sublime concept of humanity which progresses both according to its moral development and its natural evolution towards beauty. Opposed to this view of art there stands realism, which lacks the ability to interpret humanity and insofar as it captures at best an instant in time and in the existential experience of an individual can only be false to the ideal of beauty it claims to pursue as well. From this, Dreyfus draws, in a separate paragraph, the maxim that he underlines:

132 As Taine put it: "Photography is the art which completely reproduces with lines and tints on a flat surface, without possible mistake, the forms and modeling of the object imitated," The Philosophy of Art, 52). It is important to note that Dreyfus does not take such a naive position, and as we shall see argues that the very "accuracy" of the camera is what makes it distort reality, and the human imagination must interfere in this false reproduction to provide both perspective and meaning.

133 Or as Dr Johnson would say, the goal was not to count the number of stripes on the petals of a rose but to create the essence of the rose. 
Pour voir, il faut les yeux, pour comprendre, il faut l'intelligence.

To see, one must have eyes, to understand, one must have intelligence.

Just as a natural, innocent, and unsophisticated sensory perception contrasts with a moral and aesthetic understanding, so do the eyes and the trained cognitive faculties of the mind. This leads him to explicate on the contrasts between approaches to seeing and understanding, recording impressions and working towards interpretation:

It is only given to a few men, [this ability] to reveal through the phenomenon of visible beauty to invisible beauty, of man to humanity.

In a sense, Dreyfus is an elitist; he believes that not all people are created equal, that there are some born with superior talents and mental faculties, but these differences are neither racial nor national nor social in the sense of fixed classes. Men and women of genius must, having been given superior capacities, use them in whatever ways are open to them by their own personal preferences and according to the cultural discourses provided by the times and the places they live in, seek to express through the imitation of physical nature and its beauty the secret, hidden dimension of supernal beauty, a beauty that, moreover, is moral and spiritual, raising individuals from their historical matrix into the purer domain of humanity-from the fallen Adam back to the original Adam, ha'adam hakadmon. This perfectibility of perception to moral vision provides the model for all other forms of tikkun ha'alom, kabbalistic rectification of the created universe: "And that is true for all those orders of ideas in which human thought exercises itself.

But then where we might expect, under other circumstances, the argument to follow through into the Talmudic and mystical ideas they seem to be working towards, despite the secular, classical, and sometimes even Christian terminology Dreyfus writes in, he picks up the model he wrote about a few pages earlier in this second cahier: 
It is for this reason that I already said a few days ago in the study of Michelet: The facts have provided material to Michelet, to be shaped by the form of his intelligence, his thought, he knew how to give life back to (reviver) the before us, to give a soul (donner l'âme) to a people, to an epoch.

It is this historian who shows Dreyfus how beauty is produced and how to write history in a way that shapes the facts into an image of the meaningful life of a people and an epoch, so that what is produced has within it the soul that is otherwise missed in impressionistic copies and photographic reproduction. Beauty has nothing to do with proportionate harmonies or pleasing exteriors: it is in the perceived truth that is expressed through a just interpretation of a higher truth.

That which is true for History is true for Literature, for Painting, for every order of ideas where human thought exercises itself. It is not sufficient to see; one must comprehend with the eyes of the heart, with those of the soul.

To place this principle of beauty and truth into a Jewish context, we need to consider the Hebrew terminology that lies behind Dreyfus's praise of Michelet-and two other names he adds in a final short paragraph, Michelangelo in painting and Leonardo da Vinci in goldwork. This special word is hadar, הis, a form of beauty associated with splendour and glory. For example, according to Shlomo Riskin,

hiddur mitzvah is the term used to describe the performance of a commandment on the highest possible level, which includes searching out the most beautiful objects required, as well as expending extra time, effort and money. ${ }^{134}$

This way of understanding beauty goes back into Talmudic authorities, such as R. Abahu, who interprets 
hadar to also mean (in addition) to beauty the one who inhabits, literally referring to that particular fruit which lives on the branch from "generation to generation"(season to season) without suffering the natural calamities of wind, storm and rain.

Riskin extrapolates from this, along with the rabbinical tradition, that "true beauty is expressed by the citron's ability to overcome the blasts of the elements," meaning that it is not an appearance in this ethrog or any other thing that is beautiful; it is a hardiness, a capacity to endure in love, loyalty, and life-in other words, it is inner strength and character. Moreover, "hadar rises from the core of a person's being." For this reason, the Jewish notion of beauty differs radically from that set of principles coming from Hellenistic civilization, including both Christianity and the secular European cultures that derive from it.

The difference between Hellenism and Hebraism is that the former worshipped at the altar which claimed beauty was truth, while Hebrews affirmed the exact opposite, that "truth is beautiful."

Continuing his discussion of Michelet and Beauty onto the next page of his workbook, Dreyfus writes:

Michelet had radiant thoughts, the concern for truth, the pen of an artist, so as to render this truth. Michelangelo had the palette of a great artist, the thoughts of a great genius which directed his hand. What more marvellous than the birth of the human thought by the hand submitting to intelligence than the frescoes in the Sistine Chapel in Rome?

These lines embody in two different and specific artists the principles laid out on the previous pages of the essay on art. Whether Dreyfus ever himself visited Rome and saw the Sistine Chapel is unlikely, but he probably saw pictures of it in a book, and what is most important is the idea of the perfected idea as the work of art. 
Then Dreyfus repeats his argument on the limitations and deficiencies of Impressionist art, which he now identifies with realism in the philosophical sense:

The Realist violates Truth by submitting to us only a point of detail, staring into the sun with his naked eye, without a soul to comprehend and grasp. It is the Ideal which enlightens the Truth.

A passive art, in which the painter, poet, or musician acts only as a vehicle through which the external world passes, makes its impression, and then projects that impression into the work of art, is a hollow, superficial thing, an idol. This action, however, does more than set itself up to be a sounding board to resonate with external stimulus or a wind chime through which inspiration wafts to create a pleasant melody; it is a sexual violation of the naked truth. Paradoxically, this violation is itself passive, allowing oneself to engage in a self-blinding enterprise, staring with the naked eye into the sun. The lack of a soul, here standing for the active intellect well trained in the arts of the humanities, makes the artist more than a suicidal fool; by violating the truth, such an artist is a terrorist who destroys the basis of civilization. The idealist, on the other hand, the true artist, enlightens, actively interprets experience and casts the radiant beams of what is produced into the world.

Incrementally repeating what he said earlier about genius not working to dogmatic beliefs, Dreyfus mimics Lamennais's shift from strict obedience of Catholic doctrine to a call for freedom, a liberal interpretation of theology, and a tolerance of other ways to the truth:

Genius does not recognize doctrines, it only recognizes tools (outils) to give a form to its own thought. Let us salute free spirits who go in search of their inspiration in the poetry of Homer, even in the mysterious pages of the Bible, those above all who seek inspiration in the radiant book which is called Nature.

Rules and regulations serve to train the hands and the eyes of the artist, whereas set rules for what constitutes a pretty or a pleasing picture or musical composition or some other work of art would stultify ge- 
nius. But libres esprits, like Timanthes, are inspired by rhetoric of great poetry, by the deep mysteries of Scripture, and mostly by the Book of Nature, the last two words in that paragraph being underlined in the manuscript. By this concept of nature, surely he does not mean the rural scenes and cityscapes that the painters of the late nineteenth century went out into to find their subjects, unencumbered by neoclassical rules, and Dreyfus could not have been so naive about contemporary art as to pass over their dependence on the masters of the previous generations and the models they copied in museums in Paris and Rome to train themselves, even when they rejected the strictures of the Salon juries and official patrons of the state. Yet there is something bizarre and troubling in his conclusions here, something that makes his argument ring hollow, even when it has the resonance of rabbinical themes. Thus, the final paragraphs, beginning with this odd paean to pantheists and deists, is hardly comprehensible either in import or in tone, given the fragmented state of the words:

Pantheists or deists [three words illegible] all those who adhere to the cult of Beauty in these two concepts the Ideal and the [illegible word] Truth.

This would be a positive statement by the writer of the cahier, but does he really favour these forms of religious thought, pantheists perhaps finding their most authoritative model in someone like Spinoza in the seventeenth century and deists in the followers of Locke in the eighteenth? The next sentence, separated into a new paragraph, either repeats or attempts to advance that thought:

Thus, pantheists or deists, it matters little, let us salute those who adhere to the cult of Beauty, in these two concepts, the Ideal and the Truth.

Does it matter whether we call such persons pantheists or deists, or are they of little significance themselves, and the call to praise them ironic, self-mocking, because although they exalt the concepts of the ideal and the truth they do not have the mental or spiritual capacities to interpret what they see and try to reproduce in their works? What was Dreyfus trying to say in the words that are now illegible in the first 
version of this statement? We will probably never know. Yet he gives a slight hint in the short citation from the Vulgate that follows:

Post tenebras spero lucem.

After the shadows, I hope or seek for the light.

This has been taken by Calvin and others within Protestantism to stand for a saying such as "After the Darkness, the Light," referring to Christ. The fuller text is found in Job 17:11-13, which in the Vulgate reads:

Dies mei transierunt cogitationes meae dissipatae sunt torquentes cor meum noctem verterunt in diem et rursum post tenebras spero lucem si sustinuero infernus domus mea est in tenebris stravi lectulum meum

The Authorized Version in the Knox edition translates this, emphasizing the Protestant interpretation of the text:

My days are past, my purposes are broken off, even the thoughts of my heart;

They change the night into day: the light is short because of darkness.

If I wait, the grave is mine house: I have made my bed in the darkness.

The translation into French by Louis Segond, first published in 1873, from both the Hebrew and the Greek Septuaguint and thus likely to have been seen by Dreyfus, reads:

Quoi! Mes jours sont passés, mes projets sont anéantis,

Les projets qui remplissaient mon cœur...

Et ils prétendent que la nuit c'est le jour,

Que la lumière est proche quand les ténèbres sont là!

C'est le séjour des morts que j'attends pour demeure,

C'est dans les ténèbres que je dresserai ma couche...

Would Dreyfus have recognized these differences in translation and in religious perspective, or would he only have seized upon the 
most obvious metaphorical meaning of the text as a saying? On the one hand, it would be interesting to examine very closely the original context in the Book of Job, which we have studied in the past, ${ }^{135}$ and show, in collaboration with Israel David, that this Book of Wisdom has a special concern with breaking apart the dogmatic readings of both scriptural and liturgical imagery in order to forge a version of Judaism which, along with Ecclesiastes and the Song of Songs, for instance, is nonmythical and that calls for philosophical as well as legal interpretations of the language through a pre-Maimonidean rationalism. On the other hand, paying more attention to the context of the essay on art, it would be useful to accept the metaphors of light and darkness in their non-Jewish acceptations, with only slight modifications to follow the argument of Dreyfus. Nevertheless, given that in this citation Dreyfus authorizes us to confirm his knowledge of the Bible-that mysterious book he places second after Homer and behind the Book of Nature, unless the lines quoted above were ironically conceived-it is possible to take the analogy between his condition on Devil's Island and Job's on the dung heap as more than an imposed juxtaposition; it can be a conscious identification he makes with the great man suddenly and unfairly brought low, despondent but roused to rage against his erstwhile friends who take his losses and afflictions as proof positive of his guilt, since the God of their religion would never do an injustice, and his denials of any slight confirmation of their position as further evidence of why he deserves to be ruined for his arrogance and pride-and eventually alienated from God.

At first the deity seems to confirm the case against Job until, remarkably, the voice from the whirlwind returns to proclaim that Job was correct to rail against his friends and young Elihu, and that, indeed, a man must demand accountability from the justice of Heaven and not accept the apparent punishment as a given. In this sense, the darkness would be the deaths, the losses, the illnesses, and the rejection by his friends, and the light would be, not Jesus coming into the world as Light

135 Norman Simms and Israel David, "God's Answer to Job: Revelation and Confession," Simms, ed., In a Season of Hate: Selection of Papers from the Proceedings of the Tenth Biennial Waikato Jewish Studies Seminar (Hamilton: Outrigger Publishers, 2002), 52-56. See also "Theodicy and Job in Three Eighteenth-Century Novels," Serge Soupel, ed., Crime et Châtiment dans les îles britaniques au dix-huitième siècle (Paris: RBC, 2001), 201-222 and "The Alienated Woman: or, Mrs. Job Suffered Too," Vladimir M. Bychenkov, ed., Anonymity, Impersonality, Virtuality (Moscow: Russian and British Cathedra, 2002), 280-297. 
or Truth incarnate, but the very reason that interprets the illusions and delusions the friends and Elihu recite uncritically and irrationally. Job the man and Job the long dramatic or rhetorical poem are each works of art, beautiful because they manifest truth and truth is beautiful. That truth is what interpretation creates, not what is given, to be taken passively and on faith. Alfred Dreyfus is also still waiting and hoping for the truth to emerge, and although he and Lucie have said that such enlightenment will break into the world unexpectedly, they also know that such an event will happen only because they have, each in their own way, remained steadfast in their love and loyalty, endured the pains and humiliations thrown upon them by a hostile and bigoted world, and worked hard to produce the change in interpretation of the facts and the exposure of the forgeries.

The essay on art, however, concludes lamely, with a statement that Leonardo da Vinci "gives the supreme example" of how a great artist has "revealed the soul in painting the body, in chiselling the material." More irony through understatement or overstatement? Indirection, as the rabbis often counsel, to put the censors off balance? Who knows? But after a brief reading of a poem by Vienne on King John, ${ }^{136}$ in which Queen Isabelle's plea is rebuffed because "you are only a woman," Dreyfus adds a word on Henry IV:

However brave he was, when one came to say to him, "Here are the enemies," it was always taken as a kind of canting (dévoiment), and he shut him off in raillery and said, "I am going to do something good for them."

This leads into another aphorism that might come from La Rouchefoucauld or some other cynical thinker of the past:

Personne n'est grand pour son valet de chambre.

No one is great to his personal servant.

All three of these little comments can be seen to show that what you say has its effect more because of who you are than through the value of the remark itself. Truth is normally a social construct and 
does not shape words into things of beauty.

The next significant essay in cahier 2 is the one on photographic equipment. ${ }^{137}$ Yet having said that, the reader must not expect a highly technical disquisition on the mechanics of optics and the latest developments in the construction of the machinery used to fix images on plates or the advance towards motion pictures occurring at the time Dreyfus was writing this short piece. Rather, two features make it significant: one is that the essay concerns itself, at least in the opening paragraph, with the implications of this technical method of reproducing and storing images, already available for at least fifty years and known to a wide public, with many artists coming to understand its potential as an art form in itself, and the second is that for the first time in his cahiers, Dreyfus, under the same underlined title, swerves to a seemingly very different topic altogether.

Thus, of the five paragraphs in this little essay on folio 35, actually only two concern themselves with photography. The first announces the theme, perhaps taking as a starting point some article he has read in one of the magazines sent to him:

It is one thing amateur photographers fail to take account of. In photographic equipment, one has, according to circumstances, copied the fashion (la façon) of making man and most animals, or the fashion (la façon) of making a fish in order to make an objective point.

In the repetition of façon, he introduces the primary ambiguity in his thought. Amateur photographers, who now have at their disposal smaller, less unwieldy apparatus that makes it possible to take their own pictures for whatever purposes they may choose, do not act as though they had total freedom to follow their own inclinations but "follow the fashion," in the sense both of selecting objects to take pictures of and deciding how to arrange the object in a setting and in the sense of already perceiving the final product according to current styles and modes they have seen in galleries and illustrated magazines, that is, fashion in the sense of being à la mode.

The third and fourth paragraphs deal with the organic chemistry of 
fat and the implications for human health, and the fifth with a great chemist calling on his students at the polytechnic to apply their learning to public health issues. The essay therefore allows us to watch Dreyfus's mind working by word associations as he slides from the original topic, with its theoretical base and moves towards implications to another subject where the same thing happens, his concern being both for the science that fascinates him and for the application of this technical knowledge in the real world for social and moral ends, his real concern throughout all the prison workbooks.

For most people, the amateurs, the circumstances in which they live have unconsciously turned the fashion, the manner in which they learn to operate the equipment and utilize to make pictures that they will enjoy looking at, showing to others, and keeping in their personal archives, into a style or mode of predetermined paradigms of perception, reception, and memorial value. What could be a mechanism for scientific exploration or artistic creation has become just another way for the powers who control the society to impose their tastes and social agenda over the broad public. These photographs of men, most animals, and fish confirm what the amateurs believe, because they have been so conditioned, man, most animals, and fish look like.

On the other hand, as the second paragraph begins to conjecture, what the objects in the outside world look like is beginning to change because the photograph does not exactly reproduce the optical mechanism of the eye, and so the use of the photographic equipment has begun to change the way in which we all see, think about, and recollect the world we live in.

When one uses spectacles, one modifies the focus of the lens; one does like a man and most animals do who, adjusting their eyes to diverse planes, vary the focal distance by changing the curvature. When, on the contrary, one focuses with a ratcheting device to vary distances between the ground-glass and the lens, which is the general case for most equipment, one operates like fish who lack the facility to change the curvature of their eyes, but can advance or return their retina to make the focus.

This seems to be pure mechanics, the science of optics: to accom- 
modate the eye's focus to objects at various distances, the mechanism can either change the focal point of the lens or move the retina back and forth, one is the usual form in mammalian eyes and the other in fish. The latest equipment for a camera oscura uses both means, what is natural for a human being and what is not. Dreyfus does not at all seem aware here of the two implications of his topic, neither of the social and aesthetic opportunities provided by the invention of the camera nor of the deeper philosophical and political implications. They are, however, implicit in his essay, because we may see them being opened in the essays already examined and will see even more in the folios to come in the remaining thirteen cahiers.

That is why the segue into the discussion of chemistry and health should be seen as significant and not merely as a random loss of attention.

Up to now, the question of organic chemistry, to know the transformation of fat in an organism, has remained more than obscure (plus qu'obscure). We certainly knew how we get fat, thanks to starches, but we hardly had any doubts about the phenomenon of getting thin. They used to believe that fats oxidize under the influence of oxygen in the air; that is false-oxygen does not oxidize fats. However. ... .

Before following Dreyfus in this new theme of science and technology, it is important to note the way in which his mind is working and the underlying pattern of his association of ideas. ${ }^{138}$ The starting point for the new thought is the advance in understanding from what has hitherto (jusqu'ici) been assumed to be true, and the shift to negation of that set of truisms (c'est faux) begins with "However" (cependant), the announcement of the new epistemological position. This is a variation on what happened when he was talking about photography and the introduction into the discussion of a counterintuitive idea, that the machinery follows both the natural or normative fashion of focusing

138 Whereas the recommended technique of "fantasy analysis" in psychohistory ignores all but the substantive and metaphorical terms in a discourse, especially rubbing out negative and subjunctive or conditional markers, so as to bring to the surface the unconscious dreamlike imagery of repressed thought, in my midrashic readings, I focus on the syntactic markers of process, transformation, and refocalization. 
on distant objects and an artificial fashion. What was once thought to be true about the oxidizing of starches proves to be false, but the new understanding comes because the doubts once under the surface of conscious thought have now broken through into moral consciousness.

What was once certain (on savait bien) was not all that secure, although it was assumed to be so because the doubts, though present, were hardly there (on ne se doutait guère). It was clear that people got fat, but one didn't know how to make them thin again because scientists misunderstood the process by which ingested starches are transformed into bodily fat. The facts don't change; what we believe does. Our assumptions therefore need to be always challenged and questioned so that we learn to see and understand in better ways, so that we come to see the truth and not a fashionable representation of a doubtful truism. Or we need to learn to step out of the obscurity of the old-fashioned camera oscura, the dark chamber of ignorance or superstition, into the camera lucida Tarde spoke about at the start of this chapter. This is what enlightenment is: not the brilliant and fixed image of truth dominating by a dogmatic assertion of its power but the constant challenging and questioning of assumptions, as Job was forced to do to rid himself of the persecution of his friends, with the ideals of the enlightenment, like Torah and Talmud, as a way of thinking and arguing towards the dynamic and always emerging and developing truth rather than the faithful reception passively of an imposed statement of an iconic truism.

Returning to the "However" where we stopped in our reading of Dreyfus's little double essay on photographic equipment and the mechanism of fat production in the body, what is important to see are these abstracted markers in his text:

However, it has been recognized . . because we believed in ... while all experiments in the laboratory demonstrated the non-existence of these facts. Through multiple experiments, an authoritative chemist arrived at the explanation-quite likely (assez vraisemblable)....

For Dreyfus, this is the ideal of science: an experimental method that disproves false assumptions and by many experiments (i.e., experiences of testing) builds up a new theory that stands as likely until it too is 
proven false and another takes its place, and so on ad infinitum. ${ }^{139}$

Then a double conclusion. The first is the logical outcome of the preceding essay, and the second is the personal memory evoked by the discussion-one of those very rare moments when Dreyfus permits himself to write about his own childhood and education.

As all that makes me recall the wishful words formulated by Cahours, my deeply missed teacher at the Polytechnic, in his last books, where he exhorted chemists of [sic] to busy themselves with the search for a more perfect knowledge of the blood in order to deduce all its physiological properties.

Perhaps the defective phrase marked sic by the modern editors should have had "chemists of the future." What Cahours had taught young Dreyfus in the Polytech was more than a body of knowledge about chemistry, it was a scientific method: from close observation and experimentation through thoughtful extrapolation of general theories to useful application of the knowledge retrieved from nature to human uses. As in art, so in science, the best practice, the beauty of the method, lies somewhere other than in a passive observation and recording of impressions. Beauty is created when it follows an active observation into and a rational transformation of the facts into the next stage of truth. Art and science are not opposites, as science and religion are not; all are variations on the same theme, using different approaches and according to the temperament, talents, and properties of each individual in the time and place of his or her existence. ${ }^{140}$

Can we be absolutely sure this is what Alfred Dreyfus meant here? No, not absolutely, but we can be tentatively comfortable with these speculations when we find them confirmed, refined, and challenged in

139 Claude Bernard (1813-1878) and his Introduction to the Study of Experimental Medicine (1865) will be discussed further in the next volume in this series.

140 Interestingly, it is Taine who comes close to saying the same sort of thing about what he calls "the ascendancy of involuntary impressions" in art: "Study the sketches, designs, diaries, and correspondence of the old masters, and you will again everywhere find the same inward process. We may adorn it with beautiful names; we may call it genius or inspiration, which is right and proper; but if you wish to define it precisely you must always verify therein the vivid spontaneous sensation which groups together the train of accessory ideas, master, fashion, metamorphose and employ them in order to become manifest" (The Philosophy of Art, 80). 
subsequent entries in his cahiers. For example, immediately following this run of three essays on truth, beauty, and perception and their epistemological, moral, and practical implications, we find two short aphoristic remarks. The first appears in cahier 2, folio 37, and the second on the verso of that page. ${ }^{141}$

Happy those who carry within themselves an ideal of Beauty, and who obey their [sic] ideal of art or the ideal of science.

Aside from the awkward grammatical formulation of this statement, ${ }^{142}$ as noted by the modern editor, the import is a clear extension of what has just been said about the way Dreyfus sees all knowledge systems ideally operating towards the same goal of a dynamic truth through different means of approach, not least the broad categories of art and science. Next comes a quotation from Pascal that Dreyfus comments on darkly:

De Pascal: "L'âme humaine a des profondeurs insondables." Il eût mieux fait dire que le cour humain avait des profondeurs de cruauté incommensurables.

By Pascal: "The human soul has its unfathomable depths." It would be better to say that the human heart has depths of incomparable cruelty.

Out of the depths of his despair, from amidst the horrible nightmare of his torments in prison, the prisoner reverses the seventeenth-century Christian thinker's aphorism. This is what science cannot understand and what art cannot reproduce in beautiful imagery-the unspeakable evil of the injustices imposed on an innocent Jew. But this way of thinking leads to madness.

In a brief critique of Victor Hugo's Angelo, Tyran de Padoue, ${ }^{143}$ Dreyfus concludes that this historical play, like others in the Romantic school, makes a flash but then is forgotten, not because it lacks energy

141 Cahiers, 75.

142 "Heureux ceux qui portent en eux un idéal de Beauté, et qui leurs obéissent, idéal de l'art ou idéal de a [sic] science."

143 Cahier 2, Folio 38, Cahiers, 76. 
or style-it has both in abundance-but because everything has been written simply for artificial effect; the whole drama of life has become a fantasy.

This essay is followed by what seems to be a totally unrelated discussion on alcoholism, ${ }^{144}$ yet as has happened before, such a scientific essay offers interesting insights into the character and personality of Dreyfus. First, there is a short description of an experiment undertaken over a period of six months in the tiny hut in which the prisoner is kept. He was trying to find an efficient means of producing commercial alcohol and methylated spirits: the attempt was unsuccessful. The discussion then veers in a slightly different direction: he asks himself why the measures of electrical current are named after famous men so that if one wished to write out one's experiments there would be a cacophony: Ohm, Ampère, Latinus Clark ... Thinking about scientific laws, he is also amused by the words used to designate the facts: this is whimsy, and for too long Dreyfus has been dismissed as a humourless and dour automaton. It is one thing to comment on the artificiality of early nineteenth-century drama and poetry, another to write about alcohol and electricity-but there is a connection in the witty mind of the writer.

After an aborted discourse on Shakespeare's Othello, wherein Dreyfus goes no further than writing the title of the essay and then crossing it out, he creates a line drawing of an empty stomach followed by a sketch of the same organ after a hefty meal. This leads into an essay on digestion. ${ }^{145}$ From a description of how food is absorbed into the body, he moves to the state of surgery on the stomach, remarking that medical science has not proceeded very far in this regard, lamenting this neglect. Is there a hint here about the poor hygiene and paucity of good food on Devil's Island and Dreyfus's own troubles with indigestion and tropical disease? That would be reason enough to turn away from the Moor of Venice.

A brief notice on Madame de Staël, ${ }^{146}$ one of many essays on persons and events connected to the last part of the ancien régime and the coming of the French Revolution and its immediate aftermath; this critique admires her because she participated in the progress and the perfect- 
ability of humanity, clearly something Dreyfus wishes he could enjoy. Then he cites two dozen verses from Hugo's Odes et Ballades, ${ }^{147}$ beginning "Que la soirée est fraîche et douce." (How fresh and sweet the evening is), a sentimental and nostalgic idyll, again perhaps attractive to Dreyfus by its dreamy invitation from the poet to the reader to join him in wandering through the evening landscape together.

From this reverie, Dreyfus glides into another essay on Jules Michelet, this time recounting the historian's biography, emphasizing how his life seemed to be marred by political events, when he was chased out of the Collège de France for refusing to take an oath of loyalty after the coup d'état, and thus going into exile, and in that exile-which Dreyfus must have looked on longingly as full of promise and renewal-developing his poetic soul. From this period of his life emerge Michelet's most lyrical, meditative books, such La Montaigne, Le Mer, L'Oiseau, L'Amour, and La Peuple, impressionistic meditations on nature and society in various forms. It is through these kinds of books, says Dreyfus, that we come to appreciate the beauty of the specifically historical studies Michelet is most famous for; a soul that teaches itself to vibrate in harmony with the environment is preparing itself to understand the moral life of mankind. And, as though comforting himself in his own despondent state, Dreyfus concludes by saying that out of a life defeated and wounded by adversity, "he returned to humanity with a stronger hope, a larger degree of pathos" (il revient ainsi à l'humanité avec un espoir plus fort, une pitié plus large).

This leads directly into one of Dreyfus's most important statements about the contemporary spirit:

Taine, Renan, Darwin, here are the three great minds which have most influenced modern ideas, more or less, following they have been more or less understood. Darwin above all has often been poorly understood. ${ }^{148}$

These are the modern thinkers Dreyfus most admires, to which list he gradually adds a few more, some artists or literary people, but most of them scientists, philosophers, and historians. They are great but they 
are misunderstood and often neglected, at least in their own lifetimes.

In the second rank behind these three, Dreyfus places John Stuart Mills and the two Spencers in England, Haeckel and Schopenhauer in Germany, and finally Nietzsche (he does not mention where he comes from: born in Germany and living in Switzerland). These all represent a trend in nineteenth-century thought towards hard-headed social, moral, and scientific theory. These foreigners raise the question about where French writers belong. They mostly are specialists who do not venture out of their fields and hardly ever generalize their findings into universal theory. All except Claude Bernard, whose introduction to the scientific method stands out as one of the great books of the century because it sets forth clearly and beautifully a theory of experimental science. ${ }^{149}$ Yet, if France is not in the first rank of science and philosophy, it is certainly to be admired for its historians, who have enriched the literature of the age.

Out of this statement comes his next critical piece, on a poem by Sully Prud'homme, "Justice." ${ }^{150}$ In this poem, Prud'homme searches for justice until he finds it in the human conscience, an idea Dreyfus approves of, although he might have better expressed it, from what we have seen in earlier essays and their affiliation with rabbinic thought, by indicating that the human soul finds its beauty and strength in justice, that is, in the law. But the poem itself, for all its admirable thoughts, is

149 Claude Bernard, "Introduction à l'étude de la medicine expérimentale" (1865), Oeuvre, Paris: J. B. Baillière et Fils, 1883. After distinguishing the scientific method from that of the metaphysician, whose scholasticism stands a block to discovering through experimentation the laws of nature, Bernard speaks of "L'expérimentateur qui se trouve en face des phénomènes naturels ressemble à un spectateur qui observe des scènes muettes. Il est en quelque sorte le juge d'instruction de la nature; seulement, au lieu d'être aux prises avec des hommes qui cherchent à le tromper par des aveux mensongers ou par de faux témoignages, il a affaire a des phénomènes naturels qui sont pour lui des personnages dont il connaît ni le langage ni les mours, qui vivent au milieu de circonstances qui lui sont inconnues, et dont il veut cependant savoir les intentions" (The experimenter finds himself face to face with natural phenomena and so resembles a spectator who observes the examination of men who seek to fool him by false vows, lies or perjury, and he thus deals with natural phenomena that are for him like persons of whom he knows neither the language nor the manners, who live in the circumstances unknown to him, and whom he wishes nevertheless to know the intentions). In other words, a true scientist is both like an investigating magistrate trying to evaluate the testimony of hostile witnesses and an anthropologist who does field studies of persons who speak, think, and feel differently from his own norms. What Dreyfus does is, as we shall see partly in the next chapter but more so in subsequent books of our own, to transfer that scientific method, with due adjustments, to the field of historiography and recreating, inadvertently, a midrashic approach to philosophy, aesthetics, and morals.

150 Cahier 2, Folio 45, Cahiers, 78. 
poorly written, too intricate and scanty: "If the thought is beautiful, the form is weak" (Si la pensée est belle, la forme est faible), and for Dreyfus not only must form and content match but beauty needs to be strongunlike his own mind and body, which he fears will succumb to the torments of his horrible exile. Of Justice like this René Cassin has written, in the very words Dreyfus would have agreed with:

Centuries have passed. Judaism has, throughout unparalleled trials, preserved its passion for justice and its desire to contribute to the defense of the rights of men of all races and origins, along the lines of the very principle with which it was entrusted two thousand years ago. The Ten Commandments, the first code of the essential duties of man, have suffered many an outrage in history and continue to suffer. Their moral authority remains intact. ${ }^{151}$

Dreyfus's second essay on photography discusses the techniques for enlargement of prints, "Amplification des épreuves photographiques."152 Like the earlier essay, the discussion has both a technical dimension on how to make enlargements and a theoretical component on why such manipulation of artificial images is necessary. A mechanical reproduction of an object out in the world does not adjust itself as the human eye and brain would adjust it in order to give a sense of perspective and depth. What is implied here, but not said explicitly, is that the human mind is creative in its apprehension of natural facts, whereas a camera only records instantaneous perceptions, impressions fixed on glass or chemical film. Photography moves from science to art when it provides the means for correcting the faults of innocent reproduction and from fact to beauty when it gives meaning to the image produced.

Does this have anything to do with the next item in cahier 2, a citation of lines from Torquato Tasso in Italian, "Sprezzata ancella a chi fo piu conserva/Di questa chioma?" (What good is it to conserve, vile slave, my long hair?) Perhaps a whim or caprice, but also, if we examine the

151 "From the Ten Commandments to the Rights of Man, "Shlomo Shoham, Of Law and Man: Essays in Honor of Haim H. Cohen (New York: Sabra Books, 1971), 25; cited by José Faur, The Horizontal Society, Section 2, 11.

152 Cahier 2, Folio 46, Cahiers, 78-79. 
last lines of this poem, a way for Dreyfus to find a strong expression for his deepest desires to live the heroic life of a soldier, even under the adverse conditions he now has to contend with and despite his tendency to weakness and despair:

Della battalglia, entro la turbe ostile

Animo ho bene, ho ben vigior che baste

A conduirti i cavalli, a portar l'aste.

I will follow you into the fire of battle, in the strongest mêlée of the enemy. I lack neither courage nor force to conduct your horses to carry these lances.

Courage, bravery, and determination: how Dreyfus wishes he could show them in battle! Does he realize the joke here, that the words he inscribes are spoken by a slave, a horse?

Whether he does or not, the next essay ${ }^{153}$ seems to be a kind of prose poem of his own, one of several he composes in the course of the cahiers. It is followed by a few other brief aphoristic and lyrical comments, the kind of mini-collection he will eventually call the mediations or random thoughts of the Solitary Man, the name he gives to himself or to the literary persona created in the workbooks. Although I will analyze these creative efforts more fully in my future work, it is important here, where we are trying to correct false impressions about Dreyfus's character and personality, to spend a few moments on some of these short compositions.

Lorsqu'un nuage noir menace la terre et cache sous son voile de sombres brouillards les sommets à la cime ambitieuse, il arrive souvent qu'une douce brise, s'échappant de la terre obscurcie [four words illegible] les vapeurs ténébreuses, et prévient, en les divisant, leur chute imminente.

When a black cloud threatens the earth and hides under its veil the sombre mists the summits of the ambitious peak, it often happens that a soft breeze, escaping from 
the darkened earth, [illegible words] the shadowy vapors, and prevents, by dividing them, their imminent fall.

This might come from any number of Romantic poets of the early nineteenth century or even some eighteenth-century landscape poems that only partly allegorize their depictions of natural phenomena. This is a rare moment of reverie for Dreyfus, one of his wished-for escapes from the seemingly endless nightmare of his life.

Then comes another composition somewhat more allegorical and tendentious, and written with a nice touch of assonance and syntactic harmony:

L'office du Temps est de mètre fin aux haines de détruire les erreurs. La gloire du Temps est de démasquer la fausseté, d'amener la vérité à la lumière, d'imprimer le sceau des siècles sur les choses, de frapper l'injuste obscurcie [?] jusqu'à ce qu'il revienne au droit [six words crossed out].

The duty of Time is to put an end to hatred, to destroy errors. The glory of Time is to unmask Falsity, to lead truth to the light, to imprint the seal of the centuries on things, to beat down obscure injustice until it returns to the law.

Turlais as editor puts a question mark in square brackets after the phrase injustice obscurcie as though that were an unexpected or incomprehensible idea, when, alas, it is the very heart of the matter. Justice has been hidden under a cloud of ignorance and bigotry; it is the enigma of why against all common sense and decency, Dreyfus was convicted of a crime he could not possibly have committed; why the officers of the army and the politicians in the government should have leapt to such illogical conclusions and pursued their quest for punishment to such cruel extremes; why it is taking so very long for Lucie and Alfred's brother Mathieu to bring about a revision of his court-martial; and why heaven and earth do not howl in protest and the voice of God does not break into the world to correct this horrible, unendurable error. In fact, with a minor few editorial changes to orthography and inserted glosses, the prayer to Time could read: 
It is the lawful duty of Time, as Zman, an ancient name for God, as the Lord of History and Eternity (Adon ha $k o l)$, to bring an end to all these hatreds against an innocent man, to destroy the false judgments of the court based on judicial errors. The glory, which is both the honor (kavod) and beauty (hadar) of the Divine Name, is to unmask the treachery and duplicity of the machinations against a loyal Frenchman, to bring the Truth into the Light, to correct the errors of the world, tikkun ha'olam, and to imprint the Seal of the Ages, another liturgical formulaic name for the Divine, on all things, that is, to sanctify this world and signal the beginning of messianic days, to beat down the most black and hateful Injustice that is hidden under the face of military honor and duty to the Republic, so as to hasten the return of rule by law, the dominance and pervasiveness of the Law, the Torah of Israel.

Or as is read out during the regular (nonholiday) evening services of Sabbath:

We therefore hope in thee, O Lord our God, that we may speedily behold the glory of thy might, when thou wilt remove the abominations from the earth, and the idols will be utterly cut off, when the world will be perfected under the kingdom of the Almighty, and all the children of the flesh will call upon thy name, when thou wilt turn unto thyself all the wicked of the earth.

It would seem difficult to believe any Jew who had grown up with the least attention to the most common prayers of his religion could not have such words, phrases, and concepts resonating in his mind, particularly in times of distress and pain.

Then the third composition in this series, what Dreyfus entitles "Distique funèbre," a funeral distich, although it runs more than two lines:

La Beauté, la Vérité, la Grâce dans toute la simplicité 
gisent, réduites en cendres.

La mort est son nid, en un cour loyal repose dans l'éternité.

Vérité et Beauté sont ensevelies.

Qu'à cette urne se rendent les vrais et les beaux et qu'ils soupirent une prière.

Beauty, Truth, Grace in all their simplicity lie here reduced to ashes.

Death is its nest, and a loyal heart reposes in eternity.

Truth and Beauty are wrapped in a shroud.

May this urn transform them into the true and the beautiful and they breathe a prayer.

In what seems a classical graveyard poem, engraved on a tombstone, the poet laments the passing of three key ideals in his philosophy, seeing in their deaths a further stage in their perfection as divine thoughts.

After this melancholy lyrical excursion, Dreyfus returns to a discussion of historiography, ${ }^{154}$ at first contrasting two schools of thought: the first, known as the descriptive school, compiles facts without comment and allows the student to draw his own conclusions; the second, the philosophical school, although Dreyfus thinks that name is foolish since there is neither philosophy nor science in it, has the goal of describing the soul of past ages, somehow, by intuition and poetic sensitivity. Unfortunately, Dreyfus does not elaborate on this method here, although he does, of course, elsewhere in the cahiers; instead, he slides into "an appreciation" on the old poem La Pucelle ("The Virgin") by Chapelain. This contemporary verse on the enthusiastic surge of Mariology and the renewed nationalist interest in Joan of Arc in the second half of the nineteenth century, seen, on the one hand, in the commercialisation of shrines like that of Lourdes and Fatima and, on the other, in a popularization of her figure in monarchist and other pseudomystical politics, as a rather bizarre conclusion to its satire.

La cabale en dit force bien.

Depuis vingt ans, on parle d'elle; 
Dans six mois, on n'en dira rien.

The cabal spoke of it with strength, for twenty years one spoke of her, and in six months she will be heard of no more.

The word cabal used here to refer to the Catholic mystical movements, say, of the Boulangists and especially of the Jesuits, was also the term of abuse for the Jewish "syndic" or conspiracy. It is difficult to know what Dreyfus means by citing these lines, other than expressing a curiosity of contemporary popular politics, without being conscious of any application to his own condition through anti-Semitic smears-although, as we have noted before, the censors reading his letters and notebooks, not being able to understand the special terms of his love and intellectualism, dismissed his scribbles and his doodles as "cabalistiques."

In another short essay on Shakespeare's Timon of Athens, ${ }^{155}$ after some discussion of the use of Plutarch as a source, Dreyfus shows special interest in the figure of a man subject to bad luck, mistreated by his friends, and susceptible to a cynical view of the world as a consequence, a powerful variation on the Job of the Hebrew Bible. He also understands that the ancients paired Timon with the Cynic philosopher Diogenes as men who tried to put into practice their moral principles, Dreyfus finding in this Greek notion of matching ideas a striking imagery to exemplify the ideas both naive and beautiful. When he considers the way in which Shakespeare depicts Timon as a man thrown into misanthropy by the change in his fortunes, Dreyfus objects, this negative view of the world not being consonant with his own ideals, despite his own tendency to fall into the same despair:

La vie n'est ni aix bons, ni aux méchants; les premiers ne reçoivent pas la recompense de leur virtu, les seconds, le châtiment de leurs crimes. La vie est aux indifférents, Cette morale n'est pas gaie.

Life is neither to the good, nor to the wicked; the first sheet that seems to have been torn from the bound volume of the cahier and numbered Folio 12. 
do not receive recompense for their virtues, the second, punishment for their crimes. Life is to the indifferent. This moral is not gay.

The two troubling words here may or may not be used ironically and the extent of their allusiveness cannot be fully determined, and yet the understanding of the Shakespearian play and Dreyfus's philosophy hinge on them. Those who are indifférents may be objective and disinterested, and this would make them scientifically inclined, a necessary and virtuous character in the dispensation of justice in courts of law as well as in laboratories conducting experiments; but they may also be insensible, numbed to the pains and humiliations of others, and consequently cruel in their strict lack of human empathy, making them dangerous persons to deal with. As for gaie, this may signal a whimsical understated response to Shakespeare's Timon by merely saying that his way of looking at the world is not a pretty or pleasant one, or the word may allude to Nietszche's essay on The Gay Science, where the German fröhliche plays on the gai saber or gaia sciensa of Provençal poetry, where it refers to the delightful and pleasurable arts of love. Nietzsche writes with a mordant wit, mocking the developments of science and philosophy in his own times, and yet suggesting a way of creatively moving towards a more consolatory and comforting view of the world. 